\title{
Nano-Azo Ligand and Its Superhydrophobic Complexes: Synthesis, Characterization, DFT, Contact Angle, Molecular Docking, and Antimicrobial Studies
}

\author{
Gehad G. Mohamed (D), Walaa H. Mahmoud, and Ahmed M. Refaat \\ Chemistry Department, Faculty of Science, Cairo University, Giza 12613, Egypt \\ Correspondence should be addressed to Gehad G. Mohamed; ggenidymohamed@sci.cu.edu.eg
}

Received 28 April 2020; Revised 17 June 2020; Accepted 26 June 2020; Published 23 October 2020

Guest Editor: Ningbo Gao

Copyright (c) 2020 Gehad G. Mohamed et al. This is an open access article distributed under the Creative Commons Attribution License, which permits unrestricted use, distribution, and reproduction in any medium, provided the original work is properly cited.

\begin{abstract}
Metal complexes of the 2,2'-(1,3-phenylenebis(diazene-2,1-diyl))bis(4-aminobenzoic acid) diazo ligand $\left(\mathrm{H}_{2} \mathrm{~L}\right)$ derived from $m$ phenylenediamine and $p$-aminobenzoic acid were synthesized and characterized by different spectral, thermal, and analytical tools. The $\mathrm{H}_{2} \mathrm{~L}$ ligand reacted with the metal ions $\mathrm{Cr}(\mathrm{III}), \mathrm{Mn}(\mathrm{II}), \mathrm{Fe}(\mathrm{III}), \mathrm{Co}(\mathrm{II}), \mathrm{Ni}(\mathrm{II}), \mathrm{Cu}(\mathrm{II}), \mathrm{Zn}(\mathrm{II})$, and $\mathrm{Cd}(\mathrm{II})$ as $1: 1$ stoichiometry. All complexes displayed an octahedral geometry according to the electronic and magnetic moment measurements. The IR spectra revealed the binding of the azo ligand to the metal ions via two azo nitrogen atoms and protonated carboxylate $\mathrm{O}$ in a neutral tetradentate manner. Both IR and ${ }^{1} \mathrm{H}$ NMR spectra documented the involvement of the carboxylate group without proton displacement. The thermal studies pointed out that the complexes had higher thermal stability comparable with that of the free ligand. SEM images revealed the presence of the diazo ligand and its Cd(II) complex in a nanostructure form. The contact angle measurements proved that the $\mathrm{Cd}(\mathrm{II})$ complex can be considered as a superhydrophobic material. The molecular and electronic structure of $\mathrm{H}_{2} \mathrm{~L}$ and $\left[\mathrm{Cd}\left(\mathrm{H}_{2} \mathrm{~L}\right) \mathrm{Cl}_{2}\right] \cdot \mathrm{H}_{2} \mathrm{O}$ were optimized theoretically, and the quantum chemical parameters were calculated. The biological activities of the ligand, as well as its metal complexes, have been tested in vitro against some bacteria and fungi species. The results showed that all the tested compounds have significant biological activities with different sensitivity levels. The binding between $\mathrm{H}_{2} \mathrm{~L}$ and its $\mathrm{Cd}(\mathrm{II})$ complex with receptors of the crystal structure of $S$. aureus (PDB ID: 3Q8U), crystal structure of protein phosphatase (PPZ1) of Candida albicans (PDB ID: 5JPE), receptors of breast cancer mutant oxidoreductase (PDB ID: 3HB5), and crystal structure of Escherichia coli (PDB ID: 3T88) was predicted and given in detail using molecular docking.
\end{abstract}

\section{Introduction}

Azo compounds were highly colored compounds. They had widespread use as dyes and pigments in a variety of applications including fibers, coloring a large variety of leather, clothing, food, toys, medical devices, plastics, cosmetics, and dyeing of textile, as well as nonlinear and photo electronics, especially in optical information storage, biological medical studies, and advanced applications in organic synthesis [1-3]. In the development of metal complexes, the design and synthesis of a ligand was the most important step. They exhibited unique properties and novel reactivity due to electron-donor, electron-acceptor properties, structural, functional groups, and the position of the ligand in the coordination sphere $[4,5]$. Azo dyes with hydrophobic characters have wide applications especially when these dyes exhibit superhydrophobic characters. Some applications of water repellency include clothing that will be both breathable and water repellant, umbrellas that stayed completely dry, building materials, paints, epoxies, and silicones. Superhydrophobic paints and epoxies could greatly reduce the cost of transporting goods, also eliminate many of the effects of ice storms and aircraft icing. Low-permeability paint, used as a water and vapor barrier, is the standard way of protecting metal surfaces from corrosion. Superhydrophobic biomaterials are also being evaluated in more 
demanding biological applications, such as the prevention of blood coagulation and drug delivery [6, 7].

New diazo ligand $\left(\mathrm{H}_{2} \mathrm{~L}\right)$ has the IUPAC name 2,2'-(1,3phenylenebis(diazene-2,1-diyl))bis(4-aminobenzoic acid) (Scheme 1). This piece of work had devoted with the aim to synthesize $\mathrm{Cr}(\mathrm{III}), \mathrm{Mn}(\mathrm{II}), \mathrm{Fe}(\mathrm{III}), \mathrm{Co}(\mathrm{II}), \mathrm{Ni}(\mathrm{II}), \mathrm{Cu}(\mathrm{II})$, $\mathrm{Zn}(\mathrm{II})$, and $\mathrm{Cd}(\mathrm{II})$ complexes with the new diazo ligand and to examine their physical properties involving spectral behaviors and the electrical conductance values, and to determine the efficiency of the synthesized complexes against pathogenic bacteria. The molecular structure and molecular docking were also carried out in order to illustrate the way of bonding of the azo ligand and its complexes with receptors of the crystal structure of $S$. aureus (PDB ID: 3Q8U), crystal structure of protein phosphatase (PPZ1) of Candida albicans (PDB ID: 5JPE), receptors of breast cancer mutant oxidoreductase (PDB ID: 3HB5), and crystal structure of Escherichia coli (PDB ID: 3T88). In view of these findings, the contact angle measurements were performed to study the hydrophobic characters of the prepared compounds.

\section{Experimental}

\subsection{Materials and Measurements}

2.1.1. Materials and Reagents. The chemicals used were of highest purity available and pure grade. Most of them were used without further purification. $m$-Phenylenediamine (Sigma), p-aminobenzoic acid (VEB Berlin-Chemie), $\mathrm{CrCl}_{3} \cdot 6 \mathrm{H}_{2} \mathrm{O}$ (Sigma), $\mathrm{MnCl}_{2} \cdot 2 \mathrm{H}_{2} \mathrm{O}$ (Sigma), $\mathrm{NiCl}_{2} \cdot 6 \mathrm{H}_{2} \mathrm{O}$ (BDH), $\quad \mathrm{FeCl}_{3} \cdot 6 \mathrm{H}_{2} \mathrm{O}$ (Sigma), $\mathrm{CoCl}_{2} \cdot 6 \mathrm{H}_{2} \mathrm{O}$ (Aldrich), $\mathrm{CuCl}_{2} \cdot 2 \mathrm{H}_{2} \mathrm{O}$ (Merck), $\mathrm{ZnCl}_{2}$ (Strem Chemicals), and $\mathrm{CdCl}_{2}$ (Aldrich) were used. Organic solvents were spectroscopic pure from $\mathrm{BDH}$ and included ethanol and N,N-dimethylformamide. Hydrochloric acid, sodium nitrite, and sodium acetate (AR) were used.

2.1.2. Solutions. $1 \times 10^{-3} \mathrm{M}$ stock solutions of complexes were prepared by dissolving the appropriate amount of the complexes in DMF. It was used for conductivity measurement. For UV-Vis spectra measurement, $1 \times 10^{-4}$ or $1 \times 10^{-5} \mathrm{M}$ solutions of the diazo ligand and metal complexes were prepared by accurate dilution from the previously prepared stock solutions.

2.1.3. Measurements. Electronic and ${ }^{1} \mathrm{H}$ NMR spectra were carried out at room temperature using Shimadzu 3101PC spectrophotometer and $300 \mathrm{MHz}$ Varian-Oxford Mercury, respectively. For ${ }^{1} \mathrm{H}$ NMR spectra, solution of DMSO- $d_{6}$ was used, and TMS was used as an internal standard. FT-IR spectra were recorded on a PerkinElmer 1650 spectrometer $\left(4000-400 \mathrm{~cm}^{-1}\right)$ in $\mathrm{KBr}$ pellets. Electron spin resonance spectra were also recorded on the JES-FE2XG ESR spectrophotometer at Microanalytical Center, Tanta University. Microanalyses of carbon, hydrogen, and nitrogen were carried out at Microanalytical Center, Cairo University, Egypt, using CHNS-932 (LECO) Vario Elemental Analyzer. Analyses of the metals were conducted by dissolving the solid complexes in concentrated $\mathrm{HNO}_{3}$ and dissolving the residue in deionized water. The metal content was carried out using inductively coupled plasma atomic absorption spectrometry (ICP-AES), Egyptian Petroleum Research Institute. Mass spectra were recorded by the EI technique at $70 \mathrm{eV}$ using the MS-5988 GS-MS Hewlett-Packard instrument at Microanalytical Center, National Center for Research, Egypt. The molar magnetic susceptibility was measured on powdered samples using the Faraday method. The diamagnetic corrections were made by Pascal's constant, and $\mathrm{Hg}\left[\mathrm{Co}(\mathrm{SCN})_{4}\right]$ was used as a calibrant. Molar conductivities of $10^{-3} \mathrm{M}$ solutions of the solid complexes in DMF were measured using the Jenway 4010 conductivity meter. The thermogravimetric analyses (TG and DTG) of the solid complexes were carried out from room temperature to $800^{\circ} \mathrm{C}$ using a Shimadzu TG-50H thermal analyzer. The $\mathrm{X}$-ray powder diffraction analyses were carried out by using Philips Analytical X-ray BV, diffractometer-type PW 1840. Radiation was provided by the copper target $(\mathrm{Cu}$ anode $2000 \mathrm{~W}$ ) high-intensity X-ray tube operated at $40 \mathrm{KV}$ and $25 \mathrm{~mA}$, and SEM (scanning electron microscopy) for these samples was performed at the Egyptian Mineral Resources Authority, using SEM Model Quanta 250 FEG (field emission gun) attached with an EDX unit (energy-dispersive $\mathrm{X}$-ray analyses), with accelerating voltage $30 \mathrm{KV}$, magnification $14 \mathrm{x}$ up to $1,000,000$ and resolution for Gun.1n. Contact angle was measured by the contact-angle Attension Theta model (version 2.7), Biolin Scientific company, Finland, Egyptian Nanotechnology Center (EGNC). The heavy phase was water, where the volume of drop was $4 \mathrm{~mL}$, and the light phase was air. Divergence and the receiving slits were 1 and 0.2, respectively. The antimicrobial activities were carried out at Microanalytical Center, Cairo University, Egypt.

2.2. Synthesis of 2,2'-(1,3-Phenylenebis(diazene-2,1-diyl)) bis(4-aminobenzoic Acid) $\left(\mathrm{H}_{2} \mathrm{~L}\right)$. m-Phenylenediamine ( $2 \mathrm{~g} /$ $0.01 \mathrm{~mol}$ ) was dissolved in $50 \mathrm{ml}$ of ethanol, while $10 \mathrm{ml}$ concentrated hydrochloric acid was diluted with about $60 \mathrm{~g}$ of crushed ice; then, dropwise addition of $m$-phenylenediamine solution to the crushed ice was carried out. To this cold solution, sodium nitrite $(5 \mathrm{~g} / 20 \mathrm{~mL}$ water) was added and stirred for about $1 \mathrm{~h}$ till dark reddish colored solution was obtained. The coupling agent $p$-aminobenzoic acid $(5.6 \mathrm{~g} / 0.02 \mathrm{~mol})$ was dissolved in $50 \mathrm{ml}$ of ethanol and then was added to the cold mixture. The resulting solution was stirred well, and sodium acetate ( $3 \mathrm{~g}$ ) was added to neutralization. The solid product was removed by filtration, washed with hot ethanol followed by diethyl ether, and dried in a vacuum desiccator over anhydrous calcium chloride. Preparation of the $\left(\mathrm{H}_{2} \mathrm{~L}\right)$ ligand pathway is shown in Scheme 1.

Yield $90 \%$; m.p. $>300^{\circ} \mathrm{C}$; reddish brown solid. Anal. Calcd for $\mathrm{C}_{20} \mathrm{H}_{16} \mathrm{~N}_{6} \mathrm{O}_{4}$ (\%): C, 59.20; H, 3.96; N, 20.70. Found (\%): C, 58.74; H, 3.58; N, 20.17. IR ( $\left.\nu, \mathrm{cm}^{-1}\right): 3433 \mathrm{br}$ $(\mathrm{OH}), 1603 \mathrm{~m}(\mathrm{~N}=\mathrm{N}), 1660 \mathrm{~m} \quad(\mathrm{C}=\mathrm{O}$ carboxylic $), 1543 \mathrm{~s}$ $\left(\mathrm{COO}_{\text {asym }}\right), 1384 \mathrm{~m}\left(\mathrm{COO}_{\text {sym }}\right) .{ }^{1} \mathrm{H}$ NMR $(300 \mathrm{MHz}$, DMSO$\mathrm{d} 6, \delta, \mathrm{ppm}): 7.25-7.91(\mathrm{~m}, 10 \mathrm{H}, \operatorname{Ar}-\mathrm{H}), 4.78 \mathrm{ppm}(\mathrm{s}, 4 \mathrm{H}$, 


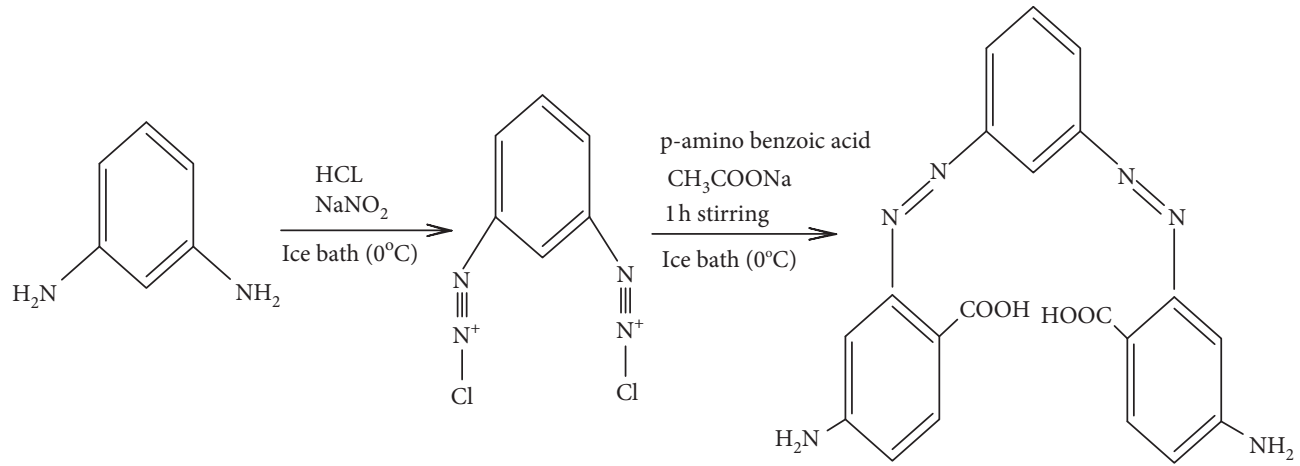

Scheme 1: Pathway of formation of the $\mathrm{H}_{2} \mathrm{~L}$ diazo ligand.

$\left.\mathrm{NH}_{2}\right)$ and $10.12 \mathrm{ppm}(\mathrm{s}, 2 \mathrm{H}, \mathrm{COOH})$. UV-visible $\left(\lambda_{\max }, \mathrm{nm}\right)$ : $375\left(\pi-\pi^{*}\right), 271\left(n-\pi^{*}\right)$.

2.3. Synthesis of Metal Complexes. $\mathrm{H}_{2} \mathrm{~L}$ ligand $(0.45 \mathrm{~g} /$ $1.11 \mathrm{mmol}$ ) was dissolved in the mixture of $30 \mathrm{ml} \mathrm{DMF}$. Then, the metal chloride salts $(1.11 \mathrm{mmol})$ were dissolved in $10 \mathrm{ml}$ ethanol, and their hot solutions were added to the clear hot solution of the diazo ligand. The precipitated complexes were filtered and collected. They were washed with a little amount of ethanol and dried over vacuum. The route of synthesis is shown in Scheme 2.

2.3.1. $\left[\mathrm{CrH}_{2} \mathrm{LCl}_{2}\right] \mathrm{Cl} .2 \mathrm{H}_{2} \mathrm{O}$. Yield 92\%; dark red; m.p. $>300^{\circ} \mathrm{C}$. Anal. Calcd for $\mathrm{Cr}\left(\mathrm{C}_{20} \mathrm{H}_{20} \mathrm{Cl}_{3} \mathrm{CrN}_{6} \mathrm{O}_{6}\right)(\%)$ : C, 40.61; H, 3.34; N, 14.03; Cl, 17.79; Cr, 8.23. Found (\%): C, 40.85; H, 3.05; N, 14.23; Cl, 17.46; Cr, 8.68. IR $\left(\nu, \mathrm{cm}^{-1}\right)$ : 3423br $(\mathrm{OH}), 1610 \mathrm{sh}(\mathrm{N}=\mathrm{N}), 1655 \mathrm{sh}(\mathrm{C}=\mathrm{O}$ carboxylic $)$, $1534 \mathrm{~m}\left(\mathrm{COO}_{\text {asym }}\right), 1402 \mathrm{w}(\mathrm{COO}$ sym $), 537 \mathrm{w}(\mathrm{M}-\mathrm{O}), 426 \mathrm{w}$ $(\mathrm{M}-\mathrm{N})$. UV-visible $\left(\lambda_{\max }, \mathrm{nm}\right): 286\left(\pi-\pi^{*}\right), 388\left(n-\pi^{*}\right)$. Diffuse reflectance: $28,489,24,780$, and $13,449 \mathrm{~cm}^{-1}$ for ${ }^{4} \mathrm{~A}_{2 \mathrm{~g}}(\mathrm{~F}) \longrightarrow{ }^{4} \mathrm{~T}_{2 \mathrm{~g}}(\mathrm{~F}),{ }^{4} \mathrm{~A}_{2 \mathrm{~g}}(\mathrm{~F}) \longrightarrow{ }^{4} \mathrm{~T}_{1 \mathrm{~g}}(\mathrm{~F})$, and ${ }^{4} \mathrm{~A}_{2 \mathrm{~g}}(\mathrm{~F}) \longrightarrow$ ${ }^{4} \mathrm{~T}_{2 \mathrm{~g}}(\mathrm{P})$.

2.3.2. $\left[\mathrm{MnH}_{2} \mathrm{LCl}_{2}\right]$. Yield 85\%; pale green solid; m.p. $>300^{\circ} \mathrm{C}$. Anal. Calcd for $\mathrm{Mn}\left(\mathrm{C}_{20} \mathrm{H}_{16} \mathrm{Cl}_{2} \mathrm{MnN}_{6} \mathrm{O}_{4}\right)(\%)$ : C, 44.20; H, 3.00; N, 15.80; Cl, 13.30; Mn, 10.49. Found (\%): C, 44.54; H, 3.20; N, 15.34; Cl, 12.86; Mn, 10.37. IR $\left(\nu, \mathrm{cm}^{-1}\right)$ : $3423 \mathrm{br}(\mathrm{OH}), 1599 \mathrm{~m}(\mathrm{~N}=\mathrm{N}), 1655 \mathrm{~s}(\mathrm{C}=\mathrm{O}$ carboxylic $)$, $1553 \mathrm{~m}\left(\mathrm{COO}_{\text {asym }}\right), 1389 \mathrm{~s}\left(\mathrm{COO}_{\text {sym }}\right), 556 \mathrm{w}(\mathrm{M}-\mathrm{O}), 439 \mathrm{w}$ $(\mathrm{M}-\mathrm{N})$. UV-visible $\left(\lambda_{\max }, \mathrm{nm}\right): 269\left(\pi-\pi^{*}\right), 374\left(n-\pi^{*}\right)$. Diffuse reflectance: $26,645,19,648$, and $15,660 \mathrm{~cm}^{-1}$ for ${ }^{4} \mathrm{~T}_{1 \mathrm{~g}} \longrightarrow{ }^{6} \mathrm{~A}_{1 \mathrm{~g}},{ }^{4} \mathrm{~T}_{2 \mathrm{~g}}(\mathrm{G}) \longrightarrow{ }^{6} \mathrm{~A}_{1 \mathrm{~g}}$, and ${ }^{4} \mathrm{~T}_{1 \mathrm{~g}}(\mathrm{D}) \longrightarrow 6 \mathrm{~A}_{1 \mathrm{~g}}$ transitions.

2.3.3. $\left[\mathrm{FeH}_{2} \mathrm{LCl}_{2}\right] \mathrm{Cl} \cdot \mathrm{H}_{2} \mathrm{O}$. Yield 93\%; black solid; m.p. $>300^{\circ} \mathrm{C}$. Anal. Calcd for $\mathrm{Fe}\left(\mathrm{C}_{20} \mathrm{H}_{18} \mathrm{Cl}_{3} \mathrm{FeN}_{6} \mathrm{O}_{5}\right)$ (\%): C, 41.02; H, 3.07; N, 14.63; Cl, 18.41; Fe, 9.32. Found (\%): C, 41.27; H, 3.29; N, 14.35; Cl, 18.27; Fe, 9.57. IR $\left(\nu, \mathrm{cm}^{-1}\right)$ : 3442br $(\mathrm{OH}), 1600 \mathrm{sh}(\mathrm{N}=\mathrm{N}), 1563 \mathrm{~s}(\mathrm{C}=\mathrm{O}$ carboxylic $)$, $1555 \mathrm{~m}\left(\mathrm{COO}_{\text {asym }}\right), 1401 \mathrm{~s}\left(\mathrm{COO}_{\text {sym }}\right), 578 \mathrm{w}(\mathrm{M}-\mathrm{O}), 442 \mathrm{w}$ $(\mathrm{M}-\mathrm{N})$. UV-visible $\left(\lambda_{\max }, \mathrm{nm}\right): 271\left(\pi-\pi^{*}\right), 363\left(n-\pi^{*}\right)$.
Diffuse reflectance: 21,490 and $20,890 \mathrm{~cm}^{-1}$ for ${ }^{6} \mathrm{~A}_{1 \mathrm{~g}} \longrightarrow \mathrm{T}_{2 \mathrm{~g}}$ $(\mathrm{G}),{ }^{6} \mathrm{~A}_{1 \mathrm{~g}} \longrightarrow{ }^{5} \mathrm{~T}_{1 \mathrm{~g}}$ and charge transfer, respectively.

2.3.4. $\left[\mathrm{CoH}_{2} \mathrm{LCl}_{2}\right]$. Yield 91\%; brown solid; m.p. $>300^{\circ} \mathrm{C}$. Anal. Calcd for $\mathrm{Co}\left(\mathrm{C}_{20} \mathrm{H}_{16} \mathrm{Cl}_{2} \mathrm{CoN}_{6} \mathrm{O}_{4}\right)(\%)$ : $\mathrm{C}, 42.90 ; \mathrm{H}$, 2.99; N, 15.60; Cl, 13.20; Co, 11.53. Found (\%): C, 43.12; H, 2.86; N, 15.11; Cl, 12.86; Co, 11.04. IR $\left(\nu, \mathrm{cm}^{-1}\right): 3425 \mathrm{br}$ $(\mathrm{OH}), 1612 \mathrm{sh}(\mathrm{N}=\mathrm{N}), 1652 \mathrm{~s} \quad(\mathrm{C}=\mathrm{O}$ carboxylic $), 1537 \mathrm{~m}$ $\left(\mathrm{COO}_{\text {asym }}\right), 1384 \mathrm{~m}\left(\mathrm{COO}_{\text {sym }}\right), 553 \mathrm{w}(\mathrm{M}-\mathrm{O}), 431 \mathrm{w}(\mathrm{M}-\mathrm{N})$. UV-visible $\left(\lambda_{\max }, \mathrm{nm}\right): 260\left(\pi-\pi^{*}\right), 343\left(n-\pi^{*}\right)$. Diffuse reflectance: $23,110,15,240$, and $12,845 \mathrm{~cm}^{-1}$ for ${ }^{4} \mathrm{~T}_{1 \mathrm{~g}}(\mathrm{~F}) \longrightarrow$ ${ }^{4} \mathrm{~T}_{2 \mathrm{~g}}(\mathrm{~F}), \quad{ }^{4} \mathrm{~T}_{1 \mathrm{~g}}(\mathrm{~F}) \longrightarrow{ }^{4} \mathrm{~A}_{2 \mathrm{~g}}(\mathrm{~F}), \quad$ and $\quad{ }^{4} \mathrm{~T}_{1 \mathrm{~g}}(\mathrm{~F}) \longrightarrow{ }^{4} \mathrm{~T}_{1 \mathrm{~g}}(\mathrm{P})$ transitions.

2.3.5. $\left[\mathrm{NiH}_{2} \mathrm{LCl}_{2}\right]$. Yield 93\%; dark brown solid; m.p. $>300^{\circ} \mathrm{C}$. Anal. Calcd for $\mathrm{Ni}\left(\mathrm{C}_{20} \mathrm{H}_{16} \mathrm{Cl}_{2} \mathrm{~N}_{6} \mathrm{NiO}_{4}\right)$ (\%): C, 43.90; H, 3.00; N, 15.71; Cl, 13.20; Ni, 11.45. Found (\%): C, 43.51; H, 2.87; N, 15.22; Cl, 13.05; Ni, 11.04. IR $\left(\nu, \mathrm{cm}^{-1}\right)$ : $3420 \mathrm{br}(\mathrm{OH}), 1611 \mathrm{~m}(\mathrm{~N}=\mathrm{N}), 1654 \mathrm{~s}(\mathrm{C}=\mathrm{O}$ carboxylic), $1537 \mathrm{~m}\left(\mathrm{COO}_{\text {asym }}\right), 1391 \mathrm{~s}\left(\mathrm{COO}_{\text {sym }}\right), 541 \mathrm{w}(\mathrm{M}-\mathrm{O}), 432 \mathrm{w}$ $(\mathrm{M}-\mathrm{N})$. UV-visible $\left(\lambda_{\max }, \mathrm{nm}\right): 287\left(\pi-\pi^{*}\right), 365\left(n-\pi^{*}\right)$. Diffuse reflectance: $26,680,14,757$, and $13,122 \mathrm{~cm}^{-1}$ for ligand-metal charge transfer $(\mathrm{LMCT}),{ }^{3} \mathrm{~A}_{2 \mathrm{~g}}(\mathrm{~F}) \longrightarrow{ }^{3} \mathrm{~T}_{2 \mathrm{~g}}(\mathrm{~F})$, ${ }^{3} \mathrm{~A}_{2 \mathrm{~g}}(\mathrm{~F}) \longrightarrow{ }^{3} \mathrm{~T}_{1 \mathrm{~g}}(\mathrm{~F})$, and ${ }^{3} \mathrm{~A}_{2 \mathrm{~g}}(\mathrm{~F}) \longrightarrow{ }^{3} \mathrm{~T}_{1 \mathrm{~g}}$ transitions.

2.3.6. $\left[\mathrm{CuH}_{2} \mathrm{LCl}_{2}\right] .3 / 2 \mathrm{H}_{2} \mathrm{O}$. Yield $91 \%$; reddish brown solid; m.p. $>300^{\circ} \mathrm{C}$. Anal. Calcd for $\mathrm{Cu}\left(\mathrm{C}_{20} \mathrm{H}_{19} \mathrm{Cl}_{2} \mathrm{CuN}_{6} \mathrm{O}_{5.5}\right)(\%)$ : C, 42.56; H, 3.76; N, 14.36; Cl, 12.91; Cu, 11.56. Found (\%): C, $42.47 ; \mathrm{H}, 3.35 ; \mathrm{N}, 14.85 ; \mathrm{Cl}, 12.55 ; \mathrm{Cu}, 11.31$. IR $\left(\nu, \mathrm{cm}^{-1}\right)$ : $3450 \mathrm{br}(\mathrm{OH}), 1614 \mathrm{~m}(\mathrm{~N}=\mathrm{N}), 1650 \mathrm{~s}(\mathrm{C}=\mathrm{O}$ carboxylic $)$, $1554 \mathrm{w}\left(\mathrm{COO}_{\text {asym }}\right), 1392 \mathrm{~m}\left(\mathrm{COO}_{\text {sym }}\right), 561 \mathrm{w}(\mathrm{M}-\mathrm{O}), 445 \mathrm{w}$ $(\mathrm{M}-\mathrm{N})$. UV-visible $\left(\lambda_{\max }, \mathrm{nm}\right): 270\left(\pi-\pi^{*}\right), 346\left(n-\pi^{*}\right)$. Diffuse reflectance: 24729 and $13290 \mathrm{~cm}^{-1}$ for ${ }^{2} \mathrm{~B}_{1 \mathrm{~g}} \longrightarrow{ }^{2} \mathrm{~B}_{2 \mathrm{~g}}$, ${ }^{2} \mathrm{~B}_{1 \mathrm{~g}} \longrightarrow{ }^{2} \mathrm{Eg}$ and ${ }^{2} \mathrm{~B}_{1 \mathrm{~g}} \longrightarrow{ }^{2} \mathrm{~A}_{1 \mathrm{~g}}$ transitions for LMCT.

2.3.7. $\left[\mathrm{Zn}\left(\mathrm{H}_{2} \mathrm{~L}\right) \mathrm{Cl}_{2}\right.$ ]. $\mathrm{H}_{2} \mathrm{O}$. Yield 95\%; reddish yellow solid; m.p. $>300^{\circ} \mathrm{C}$. Anal. Calcd for $\mathrm{Zn}\left(\mathrm{C}_{20} \mathrm{H}_{18} \mathrm{Cl}_{2} \mathrm{~N}_{6} \mathrm{O}_{5} \mathrm{Zn}\right)(\%)$ : C, 42.97; H, 3.22; N, 15.04; Cl, 12.71; Cu, 11.96. Found (\%): C, $42.81 ; \mathrm{H}, 3.07 ; \mathrm{N}, 14.88 ; \mathrm{Cl}, 12.54 ; \mathrm{Zn}, 11.54$. IR $\left(v, \mathrm{~cm}^{-1}\right)$ : 3433br $(\mathrm{OH}), 1628 \mathrm{~m}(\mathrm{~N}=\mathrm{N}), 1656 \mathrm{~s}(\mathrm{C}=\mathrm{O}$ carboxylic $)$, $1551 \mathrm{~m}\left(\mathrm{COO}_{\text {asym }}\right), 1389 \mathrm{~s}\left(\mathrm{COO}_{\text {sym }}\right), 573 \mathrm{w}(\mathrm{M}-\mathrm{O}), 429 \mathrm{w}$ $(\mathrm{M}-\mathrm{N}) .{ }^{1} \mathrm{H}$ NMR $\left(300 \mathrm{MHz}, \mathrm{DMSO}-\mathrm{d}_{6}, \delta, \mathrm{ppm}\right): 7.20-7.89$ 


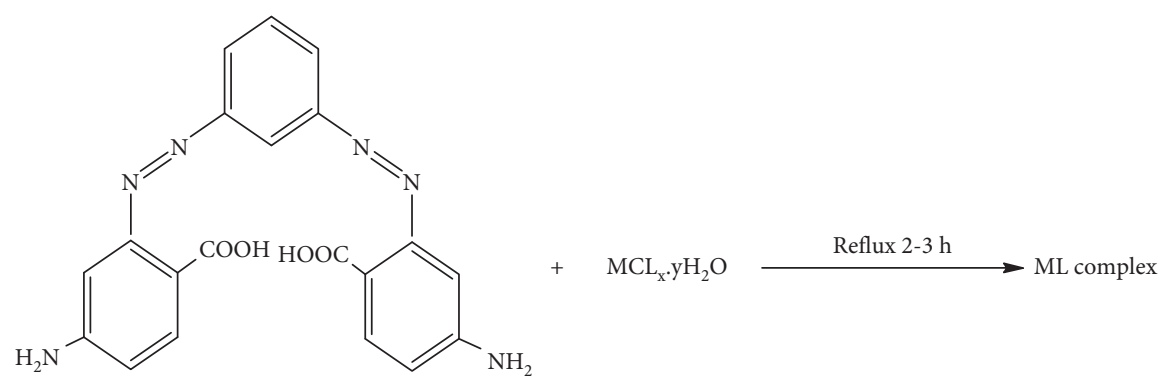

Scheme 2: Synthesis of metal complexes of the diazo ligand $\left(\mathrm{H}_{2} \mathrm{~L}\right)$.

(m, 10H, Ar-H), $4.78 \mathrm{ppm}\left(\mathrm{s}, 4 \mathrm{H}, \mathrm{NH}_{2}\right)$ and $10.40 \mathrm{ppm}(\mathrm{s}$, $2 \mathrm{H}, \mathrm{COOH})$; UV-visible $\left(\lambda_{\max }, \mathrm{nm}\right): 280\left(\pi-\pi^{*}\right), 395\left(n-\pi^{*}\right)$.

2.3.8. $\left[\mathrm{Cd}\left(\mathrm{H}_{2} \mathrm{~L}\right) \mathrm{Cl}_{2}\right] \cdot \mathrm{H}_{2} \mathrm{O}$. Yield 94\%; orange solid; m.p. $>300^{\circ} \mathrm{C}$. Anal. Calcd for $\mathrm{Cd}\left(\mathrm{C}_{20} \mathrm{H}_{18} \mathrm{CdCl}_{2} \mathrm{~N}_{6} \mathrm{O}_{5}\right)(\%)$ : C, 39.67; H, 2.97; N, 13.88; Cl, 11.73; Cu, 18.57. Found (\%): C, 39.56; H, 2.71; N, 13.68; Cl, 11.64; Cd, 18.13. IR $\left(\nu, \mathrm{cm}^{-1}\right)$ : $3450 \mathrm{br}(\mathrm{OH}), 1618 \mathrm{~m}(\mathrm{~N}=\mathrm{N}), 1656 \mathrm{~s}(\mathrm{C}=\mathrm{O}$ carboxylic $), 1538 \mathrm{~s}$ $\left(\mathrm{COO}_{\text {asym }}\right), 1390 \mathrm{~m}\left(\mathrm{COO}_{\text {sym }}\right), 546 \mathrm{w}(\mathrm{M}-\mathrm{O}), 435 \mathrm{w}(\mathrm{M}-\mathrm{N})$. ${ }^{1} \mathrm{H}$ NMR (300 MHz, DMSO-d6, $\delta$, ppm): 7.25-7.93 (m, 10H, $\mathrm{Ar}-\mathrm{H}), 4.78 \mathrm{ppm}\left(\mathrm{s}, 4 \mathrm{H}, \mathrm{NH}_{2}\right)$ and $10.38 \mathrm{ppm}(\mathrm{s}, 2 \mathrm{H}$, $\mathrm{COOH})$; UV-visible $\left(\lambda_{\max }, \mathrm{nm}\right): 275\left(\pi-\pi^{*}\right), 350\left(n-\pi^{*}\right)$.

2.4. Spectrophotometric Studies. The absorption spectra were recorded for $1 \times 10^{-4} \mathrm{M}$ solutions of the free diazo ligand and its metal complexes dissolved in DMF. The spectra were scanned within the wavelength range from 200 to $700 \mathrm{~nm}$.

\subsection{Pharmacology}

2.5.1. Antimicrobial Activity. The antimicrobial activity was carried out using the diffusion agar technique [7, 8]. LB agar media surfaces were inoculated with four investigated bacteria (Gram-positive bacteria: Bacillus subtilis and Staphylococcus aureus; Gram-negative bacteria: Neisseria gonorrhoeae and Escherichia coli) and one strain of fungi (Candida albicans) and then transferred to a saturated disk with a tested solution in the center of Petri dishes (agar plates). DMSO served as a control. All Petri dishes were incubated at $25^{\circ} \mathrm{C}$ for $48 \mathrm{~h}$ where clear or inhibition zones were detected around each disk. Antibacterial activity was calculated $[9,10]$ by subtracting the diameter of the inhibition zone resulting with dimethylformamide from that obtained in each case. Amikacin and ketokonazole were used as reference compounds for antibacterial and antifungal activities, respectively. All experiments were performed as triplicate, and data plotted were the mean value.

2.6. Computational Methodology. The electronic structure calculations of $\mathrm{H}_{2} \mathrm{~L}$ and $\mathrm{Zn}$ (II) complex were carried out using the Gaussian09 suite of program [11]. They were fully optimized employing DFT-based B3LYP method along with the LANL2DZ basis set. In order to incorporate the effect of the solvent around the molecule, the TD-DFT method (along with the LANL2DZ basis set) was used to calculate the electronic absorption spectra of the ligand and its $\mathrm{Zn}$ (II) complex. The contribution of the molecular orbital to HOMO and LUMO was also calculated.

2.7. Molecular Docking. Crystal structure of S. aureus (PDB ID: 3Q8U), crystal structure of protein phosphatase (PPZ1) of Candida albicans (PDB ID: 5JPE), receptors of breast cancer mutant oxidoreductase (PDB ID: 3HB5), and crystal structure of Escherichia coli (PDB ID: 3T88) were used in this study. Molecular docking studies were performed using MOE 2008 software [12] in order to find out the possible binding modes of the most active compounds against the above receptors. It is an interactive molecular graphics program for calculating and displaying feasible docking modes of a receptor and ligand and complex molecules. It necessitates the ligand and the receptor as the input in the PDB format. The amino acid chain was kept, and the water molecules and cocrystallized ligands were removed. The structure of complexes in the PDB file format was created by Gaussian03 software. Crystal structure of HSA (human serum albumin) (PDB ID: 5FUO), crystal structure of protein phosphatase (PPZ1) of Candida albicans (PDB ID: 5JPE), receptors of breast cancer mutant oxidoreductase (PDB ID: 3HB5), and crystal structure of Escherichia coli (PDB ID: 3T88) were downloaded from the Protein Data Bank (http://www.rcsb.org./pdb).

\section{Results and Discussion}

3.1. Characterization of the Free Diazo Ligand $\left(\mathrm{H}_{2} \mathrm{~L}\right)$. The synthesized diazo ligand $\left(\mathrm{H}_{2} \mathrm{~L}\right)$ was soluble in DMF and DMSO solvents and of high melting point which indicated its stability. From the elemental analysis data of the ligand (Supplementary Table 1), it was found that the theoretical values were in agreement with the found values. The IR spectrum of the free diazo ligand was carried out in the range of 4000-400 $\mathrm{cm}^{-1}$, and the most effective bands are listed in Supplementary Table 2. The broad band observed at $3433 \mathrm{~cm}^{-1}$ can be attributed to the $\nu(\mathrm{O}-\mathrm{H})$ stretching vibration. Also, band observed at $1660 \mathrm{~cm}^{-1}$ and sharp band at $1603 \mathrm{~cm}^{-1}$ can be attributed to $\mathrm{C}=\mathrm{O}$ stretching vibration [13] and $\mathrm{N}=\mathrm{N}$ [14], respectively. Also, the $\nu(\mathrm{COO})_{\text {asym }}$ and $v(\mathrm{COO})_{\text {sym }}$ stretching vibration bands were observed at 1543 and $1384 \mathrm{~cm}^{-1}$, respectively. 
${ }^{1} \mathrm{H}$ NMR spectrum of the free diazo ligand $\left(\mathrm{H}_{2} \mathrm{~L}\right)$ in DMSO- $d_{6}$ exhibited the following signals: $7.25-7.91 \mathrm{ppm}$ (m, 10H, Ar-H) [13], $4.78 \mathrm{ppm}\left(\mathrm{s}, 4 \mathrm{H}, \mathrm{NH}_{2}\right.$ ) [15-17], and $10.12 \mathrm{ppm}(\mathrm{s}, 2 \mathrm{H}, \mathrm{COOH})$. These signals indicated that three different types of protons were present in the diazo ligand. The position of $\mathrm{NH}_{2}$ was confirmed from carrying out the spectra in the deuterated solvent.

The mass spectrum of the ligand $\left(\mathrm{H}_{2} \mathrm{~L}\right)$ showed an accurate parent molecular ion peak at $\mathrm{m} / z 404 \mathrm{amu}$, matched with the theoretical molecular weight. Also, the mass spectrum displayed multiple peaks corresponding to successive degradation of the ligand. The base peak appeared at $m / z=134$ due to the $\left[\mathrm{C}_{7} \mathrm{H}_{6} \mathrm{NO}_{2}\right]^{+}$ion. The other fragments gave the peaks at 104,132,136,164,240, and $268 \mathrm{amu}$ with various intensities.

\subsection{Characterization of Metal Complexes}

3.2.1. Elemental Analyses. The stoichiometry and formulation of the free diazo ligand $\left(\mathrm{H}_{2} \mathrm{~L}\right)$ and its metal complexes were confirmed by their elemental analysis (Supplementary Table 1). The metal: ligand ratio was found to be $1: 1$ in all complexes, which has been arrived by estimating the carbon, hydrogen, nitrogen, chloride, and metal contents of the complexes. The elemental analyses of the ligand and its complexes revealed good agreement with the proposed structures. The ligand and its metal complexes have high melting points, and they were found to be air-stable. The diazo ligand was soluble in common organic solvents, and all the complexes were freely soluble in DMF and DMSO but insoluble in methanol, ethanol, and water. The results of elemental analyses suggested formulae $\left[\mathrm{M}\left(\mathrm{H}_{2} \mathrm{~L}\right) \mathrm{Cl}_{2}\right] \cdot \mathrm{nH}_{2} \mathrm{O}$ ( $\mathrm{M}=\mathrm{Co}(\mathrm{II}), \mathrm{Ni}(\mathrm{II}), \mathrm{Cu}(\mathrm{II}), \mathrm{Mn}(\mathrm{II}), \mathrm{Zn}(\mathrm{II})$ and $\mathrm{Cd}(\mathrm{II}))$ and $\left[\mathrm{M}\left(\mathrm{H}_{2} \mathrm{~L}\right) \mathrm{Cl}_{2}\right] \mathrm{Cl}_{\mathrm{nH}} \mathrm{O}(\mathrm{M}=\mathrm{Cr}(\mathrm{III})$ and $\mathrm{Fe}(\mathrm{III}))$.

3.2.2. Molar Conductance. The results given in Supplementary Table 1 showed that the $\mathrm{Cr}$ (III) and Fe(III) complexes had molar conductivity values of 59 and $77 \Omega^{-1} \mathrm{~mol}^{-1} \mathrm{~cm}^{2}$, respectively. It is obvious from these data that these chelates were ionic in nature, and they were electrolytes [18], but the molar conductivity values of $\mathrm{Mn}(\mathrm{II}), \mathrm{Co}(\mathrm{II}), \mathrm{Ni}(\mathrm{II}), \mathrm{Cu}(\mathrm{II}), \mathrm{Zn}(\mathrm{II})$, and $\mathrm{Cd}(\mathrm{II})$ chelates fall in the range of $11-31 \Omega^{-1} \mathrm{~mol}^{-1} \mathrm{~cm}^{2}$ indicative of their nonelectrolytic nature [14].

3.2.3. IR Spectral Studies. The infrared spectra of the $\mathrm{H}_{2} \mathrm{~L}$ ligand and its metal complexes taken in the region $4000-400 \mathrm{~cm}^{-1}$ are listed in Supplementary Table 2 which gave the most useful assignments for bands diagnostic to the mode of coordination of the ligand. The band observed at $1603 \mathrm{~cm}^{-1}$ in the free diazo ligand $\left(\mathrm{H}_{2} \mathrm{~L}\right)$ was assigned to the $v(\mathrm{~N}=\mathrm{N})$ stretching vibration. This band was found in the spectra of the complexes at $1610-1628 \mathrm{~cm}^{-1}$. Also, another band observed at $1660 \mathrm{~cm}^{-1}$ assigned to carbonyl of carboxylate $\nu(\mathrm{C}=\mathrm{O})$ at the free diazo ligand $\left(\mathrm{H}_{2} \mathrm{~L}\right)$ was found in the spectra of the complexes at $1649-1656 \mathrm{~cm}^{-1}$ (Supplementary Table 2). The shift in the azo groups of the diazo ligand confirmed the participation of the azo group in chelation.

The broad band at $3433 \mathrm{~cm}^{-1}$ observed in the diazo ligand was shifted to $3423-3450 \mathrm{~cm}^{-1}$, which was attributed to the $v(\mathrm{O}-\mathrm{H})$ stretching vibration. This shift can be attributed to the bond formation with metal ions and also the presence of hydrated water molecules. The broadening of this band may be attributed to the presence of the intramolecular hydrogen bond [19].

The $v_{\text {asym }}\left(\mathrm{COO}^{-}\right)$and $v_{\text {sym }}\left(\mathrm{COO}^{-}\right)$stretching vibrations were observed at 1543 and $1384 \mathrm{~cm}^{-1}$, respectively, for the free diazo ligand $\left(\mathrm{H}_{2} \mathrm{~L}\right)$ [19-26]. Coordination with metal ions via the carboxylate $\mathrm{O}$ atom and nitrogen atom was indicated by the shift in the position of the $v_{\text {asym }}(\mathrm{COO})$ and $v_{\text {sym }}(\mathrm{COO})$ stretching vibration bands to 1534-1555 and1384-1402 $\mathrm{cm}^{-1}$, respectively, for ligand-metal complexes.

New bands of low intensity were observed in the far-IR region in the range of $530-578$ and $427-445 \mathrm{~cm}^{-1}$ which can be assigned to $\nu(\mathrm{M}-\mathrm{O})$ and $\nu(\mathrm{M}-\mathrm{N})$ stretching vibrations, respectively [20-28]. Therefore, from the IR spectral studies, it was concluded that the $\mathrm{H}_{2} \mathrm{~L}$ ligand behaved as a neutral tetradentate ligand with $\mathrm{N}$ coordination sites and protonated carboxylate oxygen upon coordinated to the metal ions [20-27].

3.2.4. ${ }^{1} H$ NMR Spectral Studies. The ${ }^{1}$ HNMR spectra of the diazo ligand and its $\mathrm{Zn}$ (II) complex were recorded in DMSO- $d_{6}$ solution using tetramethylsilane (TMS) as the internal standard. ${ }^{1} \mathrm{H}$ NMR spectrum of the ligand revealed the following signals at $\delta=4.78\left(\mathrm{~m}, 4 \mathrm{H}, \mathrm{NH}_{2}\right), 7.05-7.94(\mathrm{~m}$, $10 \mathrm{H}, \mathrm{Ar}-\mathrm{H})$, and $10.18 \mathrm{ppm}(\mathrm{s}, 2 \mathrm{H}, \mathrm{COOH})$. The shift in the carboxylic acid protons $(10.40 \mathrm{ppm})$ indicated that oxygen of $(\mathrm{COOH})$ groups was coordinated to the $\mathrm{Zn}(\mathrm{II})$ ion. However, the singlet signal of the amino group that appeared at $\delta$ $4.78 \mathrm{ppm}\left(\mathrm{s}, 4 \mathrm{H}, \mathrm{NH}_{2}\right)$ means that the two singlet signals assigned to the two $\mathrm{NH}_{2}$ protons remained in their position as in the free diazo ligand $\left(\mathrm{H}_{2} \mathrm{~L}\right)$, confirming the remaining of these groups inert towards coordination. The upfield shift in the spectrum of the complex relative to the free ligand can be attributed to the effect of metal ions in chelation.

3.2.5. Mass Spectroscopy. The electronic mass spectrum of the $\left[\mathrm{Zn}\left(\mathrm{H}_{2} \mathrm{~L}\right) \mathrm{Cl}_{2}\right] \cdot \mathrm{H}_{2} \mathrm{O}$ complex confirmed formation of this complex by showing a molecular ion peak at $\mathrm{m} / z=540.81 \mathrm{~g} /$ mol corresponding to $\left(\mathrm{M}-\mathrm{H}_{2} \mathrm{O}\right)$, which was very close to the expected molecular weight which was $540.50 \mathrm{~g} / \mathrm{mol}$, and it also showed a peak at $\mathrm{m} / z=403 \mathrm{amu}$, respectively, corresponding to the ligand moiety. The intensities of these peaks showed the stability of the complex.

3.2.6. Spectrophotometric Studies. UV-visible spectral data of the ligand and its chelate $\left(10^{-4} \mathrm{M}\right)$ solutions in DMF were recorded from 200 to $700 \mathrm{~nm}$ at room temperature using the same solvent as blank. The free ligand $\left(\mathrm{H}_{2} \mathrm{~L}\right)$ exhibited broad bands in the UV-visible region at 375 and $271 \mathrm{~nm}$. The first band was assigned to the intraligand $n \longrightarrow \pi^{*}$ electronic 
transition. The second broad band around $271 \mathrm{~nm}$ was assigned to the $\pi \longrightarrow \pi^{*}$ electronic transition. The $n \longrightarrow \pi^{*}$ and $\pi \longrightarrow \pi^{*}$ transition bands were shifted to 339-395 and 261-285 nm, respectively, indicating that the ligand coordinated to metal ions [29, 30].

3.2.7. Magnetic Susceptibility and Electronic Spectral Studies. A comparison of the electronic spectra of the free diazo ligand $\left(\mathrm{H}_{2} \mathrm{~L}\right)$ coordinated with those of the corresponding metal complexes was discussed. This can be considered as evidence for the complex formation. Additionally, the diffused reflectance spectra of metal complexes showed different bands at different wavelengths; each one was corresponding to a certain transition which suggested the geometry of the complexes. The diffused reflectance spectra of the complexes were dominated by intense intraligand charge-transfer bands.

The diffused reflectance spectrum of the Cr(III) complex exhibited three bands at 28,489, 24,780, and $13,449 \mathrm{~cm}^{-1}$ which may be assigned to the ${ }^{4} \mathrm{~A}_{2 \mathrm{~g}}(\mathrm{~F}) \longrightarrow$ ${ }^{4} \mathrm{~T}_{2 \mathrm{~g}}(\mathrm{~F}),{ }^{4} \mathrm{~A}_{2 \mathrm{~g}}(\mathrm{~F}) \longrightarrow{ }^{4} \mathrm{~T}_{1 \mathrm{~g}}(\mathrm{~F})$, and ${ }^{4} \mathrm{~A}_{2 \mathrm{~g}}(\mathrm{~F}) \longrightarrow{ }^{4} \mathrm{~T}_{2 \mathrm{~g}}(\mathrm{P})$ spinallowed $\mathrm{d}-\mathrm{d}$ transitions, respectively. The magnetic moment value was found to be $4.81 \mathrm{BM}$ which indicated the presence of the $\mathrm{Cr}$ (III) complex in the octahedral geometry [31, 32].

The diffused reflectance spectrum of the $\mathrm{Mn}$ (II) complex showed three bands at 26,645, 19,490, and $15.660 \mathrm{~cm}^{-1}$ assignable to ${ }^{4} \mathrm{~T}_{1 \mathrm{~g}} \longrightarrow{ }^{6} \mathrm{~A}_{1 \mathrm{~g}},{ }^{4} \mathrm{~T}_{2 \mathrm{~g}}(\mathrm{G}) \longrightarrow{ }^{6} \mathrm{~A}_{1 \mathrm{~g}}$, and ${ }^{4} \mathrm{~T}_{1 \mathrm{~g}}(\mathrm{D}) \longrightarrow{ }^{6} \mathrm{~A}_{1 \mathrm{~g}}$ transitions, respectively [31]. The magnetic moment value was found to be $5.54 \mathrm{BM}$ which indicated the presence of the $\mathrm{Mn}$ (II) complex in the octahedral structure.

From the diffused reflectance spectrum, it is observed that the $\mathrm{Fe}$ (III) chelate exhibited bands at 21,490 and $20,890 \mathrm{~cm}^{-1}$, which may be assigned to the ${ }^{6} \mathrm{~A}_{1 \mathrm{~g}} \longrightarrow \mathrm{T}_{2 \mathrm{~g}}(\mathrm{G})$ and ${ }^{6} \mathrm{~A}_{1 \mathrm{~g}} \longrightarrow{ }^{5} \mathrm{~T}_{1 \mathrm{~g}}$ transitions in the octahedral geometry of the complex [33]. The observed magnetic moment value of the Fe(III) complex was found to be 5.30 BM. The reflectance spectrum of the Co(II) complex displayed bands near 23,110, 15,240 , and $12.845 \mathrm{~cm}^{-1}$, assigned to ${ }^{4} \mathrm{~T}_{1 \mathrm{~g}}(\mathrm{~F}) \longrightarrow{ }^{4} \mathrm{~T}_{2 \mathrm{~g}}(\mathrm{~F})$, ${ }^{4} \mathrm{~T}_{1 \mathrm{~g}}(\mathrm{~F}) \longrightarrow{ }^{4} \mathrm{~A}_{2 \mathrm{~g}}(\mathrm{~F})$, and ${ }^{4} \mathrm{~T}_{1 \mathrm{~g}}(\mathrm{~F}) \longrightarrow{ }^{4} \mathrm{~T}_{1 \mathrm{~g}}(\mathrm{P})$ transitions, respectively. These bands suggested an octahedral geometry for the Co(II) complex. The magnetic moment value of the $\mathrm{Co}$ (II) complex was $5.16 \mathrm{BM}$ which was consistent with the high-spin octahedral geometry.

The diffused reflectance spectrum of the $\mathrm{Ni}$ (II) complex showed absorption bands at 20,680, 14,757, and $13,120 \mathrm{~cm}^{-1}$ which are attributed to ${ }^{3} \mathrm{~A}_{2 \mathrm{~g}}(\mathrm{~F}) \longrightarrow{ }^{3} \mathrm{~T}_{2 \mathrm{~g}}(\mathrm{~F})$, ${ }^{3} \mathrm{~A}_{2 \mathrm{~g}}(\mathrm{~F}) \longrightarrow{ }^{3} \mathrm{~T}_{1 \mathrm{~g}}(\mathrm{~F})$, and ${ }^{3} \mathrm{~A}_{2 \mathrm{~g}}(\mathrm{~F}) \longrightarrow{ }^{3} \mathrm{~T}_{1 \mathrm{~g}}$ transitions, respectively, and assignable to the octahedral geometry for the Ni(II) complex [34]. The magnetic moment value of the $\mathrm{Ni}$ (II) complex was $3.80 \mathrm{BM}$ corresponding to the octahedral complex. The diffused reflectance spectrum of the $\mathrm{Cu}(\mathrm{II})$ complex exhibited broad bands in ranges 24,729 and $13,290 \mathrm{~cm}^{-1}$ assigned to ${ }^{2} \mathrm{~B}_{1 \mathrm{~g}} \longrightarrow{ }^{2} \mathrm{~B}_{2 \mathrm{~g}}$, ${ }^{2} \mathrm{~B}_{1 \mathrm{~g}} \longrightarrow{ }^{2} E_{\mathrm{g}}$ and ${ }^{2} \mathrm{~B}_{1 \mathrm{~g}} \longrightarrow{ }^{2} \mathrm{~A}_{1 \mathrm{~g}}$ transitions, respectively. These bands suggested distorted octahedral geometry for the $\mathrm{Cu}(\mathrm{II})$ complex. The magnetic moment value was found to be $1.78 \mathrm{BM}$ indicating octahedral geometry [35].
The $\mathrm{Zn}(\mathrm{II})$ and $\mathrm{Cd}(\mathrm{II})$ complexes were diamagnetic. According to the empirical formulae, an octahedral geometry was proposed for these chelates.

3.2.8. ESR Studies of the $\mathrm{Cu}(\mathrm{II})-\mathrm{H}_{2} \mathrm{~L}$ Complex. The ESR spectrum of the $\mathrm{Cu}(\mathrm{II})$ complex was recorded in DMSO at 300 and $77 \mathrm{~K}$ (Figure 1). The observed order for the $\mathrm{Cu}(\mathrm{II})$ complex $(A \|(197)>A \perp$ (98.88); g\| (2.445) $>\mathrm{g} \perp$ (2.333)) indicated that the complex exerted an octahedral geometry [35-37]. The observed value of $G$ for the $\mathrm{Cu}(\mathrm{II})$ complex $(G=1.421)$ implied that the exchange coupling was not present, and misalignment was appreciable. The trend $\mathrm{g}_{\|}>\mathrm{g}_{\perp}>\mathrm{g}_{\mathrm{e}}$ (2.0023) showed that the unpaired electron was localized in the $\mathrm{d}_{\mathrm{x} 2-\mathrm{y} 2}$ orbital of the $\mathrm{Cu}$ (II) ion in the complex [35-38]. The $g_{\text {iso }}(2.0023)$ value was less than 2.3 which indicated the covalent character of the metal-ligand bond, and the $\alpha^{2}$ value (0.76) suggested the presence of in-plane covalency. The calculated value $\left(\mathrm{g}_{\|} / \mathrm{A} \|\right) 124 \mathrm{~cm}$ for the complex was consistent with the slightly distorted structure. The orbital reduction factors $\mathrm{K}_{\|}$and $\mathrm{K}_{\perp}$ were estimated from the following expressions: $\mathrm{K} \|=(\mathrm{g} \|-2.0023) \Delta E / 8 \lambda$ and $\mathrm{K}_{\perp}=(\mathrm{g} \|-2.0023) \Delta E / 2 \lambda, \lambda=-828 \mathrm{~cm}^{-1}$ (spin-orbit coupling constant for the free ion), and $K_{\|}(0.718)>K_{\perp}$ (0.45) showed poor in-plane $\pi$ bonding.

3.2.9. Powder X-Ray Diffraction and SEM. The XRD patterns indicated crystalline nature for the $\mathrm{H}_{2} \mathrm{~L}$ diazo ligand and the Cd(II) complex only. It can be easily seen that the pattern of the $\mathrm{H}_{2} \mathrm{~L}$ diazo ligand differed from its metal complexes, which may be attributed to the formation of a well-defined distorted crystalline structure. Probably, this behavior was due to the incorporation of water molecules into the coordination sphere. On comparing the XRD spectra of the chelates with the XRD spectra of the free ligand, it was concluded that all chelates under study can be considered to have amorphous structures as they lack sharp peaks except the Cd(II) complex where it had a crystalline structure. Therefore, the nonsimilarity of the XRD pattern between the metal ions and chelates suggested that these chelates had different phase structures than the free diazo ligand $\left(\mathrm{H}_{2} \mathrm{~L}\right)$. Such facts suggested that $\mathrm{H}_{2} \mathrm{~L}$ and the $\mathrm{Cd}(\mathrm{II})$ complex were crystalline, while its $\mathrm{Cr}$ (III), $\mathrm{Mn}$ (II), Fe(III), $\mathrm{Co}(\mathrm{II}), \mathrm{Ni}(\mathrm{II}), \mathrm{Cu}(\mathrm{II})$, and $\mathrm{Zn}(\mathrm{II})$ complexes were amorphous.

The average crystallite size $(\xi)$ can be calculated from the XRD pattern according to the Debye-Scherrer equation $[39,40]$ :

$$
\xi=\frac{K \lambda}{\beta_{1 / 2} \cos \theta} .
$$

The equation uses the reference peak width at angle $\theta$, where $\lambda$ is the wavelength of the $\mathrm{X}$-ray radiation (1.541874 $\AA$ ), $K$ is a constant taken as 0.95 for organic compounds [37], and $\beta 1 / 2$ is the width at half maximum of the reference diffraction peak measured in radians. The dislocation density, $\delta$, is the number of dislocation lines per 


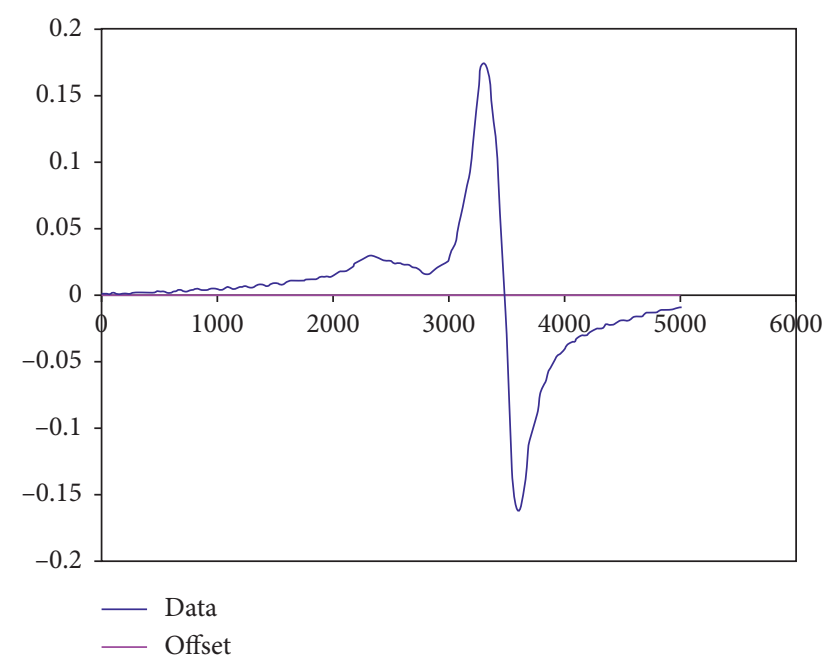

FIgURE 1: ESR spectrum of the $\left[\mathrm{Cu}\left(\mathrm{H}_{2} \mathrm{~L}\right) \mathrm{Cl}_{2}\right] \cdot 3 / 2 \mathrm{H}_{2} \mathrm{O}$ complex

unit area of the crystal. The value of $\delta$ is related to the average particle diameter $(\xi)$ by the following relation [41, 42]:

$$
\delta=\frac{1}{\xi^{2}}
$$

The value of $\delta$ was calculated and found to be 33.78 and $26.77 \mathrm{~nm}$, and the value of $\delta$ was $8.76 \times 10^{-4}$ and $1.39 \times 10^{-3}$ $\mathrm{nm}^{-2}$ for $\mathrm{H}_{2} \mathrm{~L}$ and $\mathrm{Cd}(\mathrm{II})$ complex, respectively, giving evidence for the formation of the free azo ligand and its cadmium(II) complex in a nanosize.

The SEM micrographs of $\mathrm{H}_{2} \mathrm{~L}$ and its $\mathrm{Cd}(\mathrm{II})$ are given in Figure 2. There is a significant difference in the morphological structures, and the particle size is in the nanometer range. The particle size of the ligand was $64-67 \mathrm{~nm}$, while the Cd(II) complex was $20-32 \mathrm{~nm}$.

3.2.10. Contact Angle. For two centuries or more of research, wetting phenomena still remain popular topics of investigations. Young's static and dynamic contact angle equations $[6,7]$ are the most common and relevant parameters describing the wetting property of a surface with respect to liquid water:

$$
\cos \theta_{Y}=\left(\frac{\sigma_{s v}-\sigma_{s 1}}{\sigma_{1 v}}\right),
$$

where $\theta_{Y}=$ Young's contact angle, $\sigma_{s v}=$ surface tension (energy per unit surface) of the solid-vapor interface, $\sigma_{s l}=$ surface tension of the solid-liquid interface, and $\sigma_{l v}=$ surface tension of the liquid-vapor interface.

The mean contact angles were measured for $\mathrm{H}_{2} \mathrm{~L}$ and its metal complexes (Supplementary Figure 3). The data listed in Table 1 proved that the diazo ligand and all the complexes are hydrophobic, and the $\mathrm{Cd}(\mathrm{II})$ complex can be considered as a superhydrophobic material. Superhydrophobic surfaces are actively studied across a wide range of applications and industries and are now finding increased use in the biomedical areas. A partial list includes clothing that will be both breathable and water repellant, umbrellas that stayed completely dry, building materials, paints, epoxies, goods transport, and anticorrosion. Superhydrophobic materials such as this promising nano-Cd(II) complex exhibit a number of unique properties that arise from the high roughness of a low surface energy material that stabilizes a nonwetted state $[6,7]$.

3.2.11. Thermal Analyses. Thermogravimetric analyses of the metal complexes under investigation were used to get information about the thermal stability of these new complexes, to decide whether the water molecules (if present) were inside or outside the inner coordination sphere of the central metal ion, and to suggest a general scheme for thermal decomposition of these chelates. In the present investigation, heating rates were suitably controlled at $10^{\circ} \mathrm{C}$ $\mathrm{min}^{-1}$ under nitrogen atmosphere, and the weight loss was measured from the ambient temperature up to $\sim 1000^{\circ} \mathrm{C}$. The TG curves of the complexes are listed in Table 2. The weight losses for each chelate were calculated within the corresponding temperature ranges.

The thermal decomposition process of $\mathrm{H}_{2} \mathrm{~L}$ involved three decomposition steps. Decomposition of $\mathrm{H}_{2} \mathrm{~L}$ started at $30^{\circ} \mathrm{C}$ and finished at $100^{\circ} \mathrm{C}$ with three stages. The first stage of decomposition involved the removal of four molecules of $\mathrm{NH}_{3}$ and two molecules of carbon dioxide gas in the $30-355^{\circ} \mathrm{C}$ temperature range and was accompanied by a weight loss of $36.53 \%$ (calcd. $=36.41 \%$ ). The second and third stages of decomposition occurred in the $355-1000^{\circ} \mathrm{C}$ temperature range, corresponding to the loss of the $\mathrm{C}_{18} \mathrm{H}_{4} \mathrm{~N}_{2}$ molecule and were accompanied by a weight loss of $62.76 \%$ (calcd. $=62.59 \%$ ).

Decomposition of the $\left[\mathrm{Cr}\left(\mathrm{H}_{2} \mathrm{~L}\right) \mathrm{Cl}_{2}\right] \mathrm{Cl} .2 \mathrm{H}_{2} \mathrm{O}$ complex started at $45^{\circ} \mathrm{C}$ and finished at $1000^{\circ} \mathrm{C}$ with four stages at four maxima at $79,210,377$, and $865^{\circ} \mathrm{C}$ and was accompanied by a weight loss of $80.29 \%$, corresponding to the loss of $2 \mathrm{H}_{2} \mathrm{O}$, $3 / 2 \mathrm{Cl}_{2}, 2 \mathrm{~N}_{2}, \mathrm{CH}_{4}$, and $\mathrm{C}_{17} \mathrm{H}_{12} \mathrm{NO}_{2.5}$ molecules which was very close to the calculated value of $81.53 \%$.

Thermogravimetric curve for the $\left[\mathrm{Mn}\left(\mathrm{H}_{2} \mathrm{~L}\right) \mathrm{Cl}_{2}\right]$ complex showed two weight loss events. The first step of decomposition occurred within the range of $30-435^{\circ} \mathrm{C}$, with a maximum temperature at $234^{\circ} \mathrm{C}$, and it corresponds to the loss of $\mathrm{Cl}_{2}, 2 \mathrm{~N}_{2}$ gases and $\mathrm{C}_{9} \mathrm{H}_{5} \mathrm{~N}_{2}$ molecules. The second step of decomposition occurred in the range of $435-1000^{\circ} \mathrm{C}$ with the maximum temperature at $595^{\circ} \mathrm{C}$. There were significant mass loss events due to the decomposition of the $\mathrm{C}_{4} \mathrm{H}_{11} \mathrm{O}_{3}$ molecule (Table 2).

The thermal decomposition of the $\left[\mathrm{Fe}\left(\mathrm{H}_{2} \mathrm{~L}\right) \mathrm{Cl}_{2}\right] \mathrm{Cl}_{2} \mathrm{H}_{2} \mathrm{O}$ complex proceeded via five degradation steps. The first step of decomposition occurred within the temperature range from 45 to $100^{\circ} \mathrm{C}$, with a maximum temperature at $75^{\circ} \mathrm{C}$, and it corresponds to the loss of one water molecule of hydration. The second step of decomposition occurred in the range of $100-355^{\circ} \mathrm{C}$, with one maxima at $244^{\circ} \mathrm{C}$, and corresponds to the elimination of $3 / 2 \mathrm{Cl}_{2}, 3 \mathrm{~N}_{2}, 3 \mathrm{CH}_{4}$, and $\mathrm{CO}_{2}$ with a mass loss of $47.89 \%$ (calcd. $=48.33 \%)$. The last three steps of decomposition occurred within the temperature range of $355-1000^{\circ} \mathrm{C}$ with three maxima at 485,565 , and $803^{\circ} \mathrm{C}$ and were simultaneously decomposed to ferric oxide 

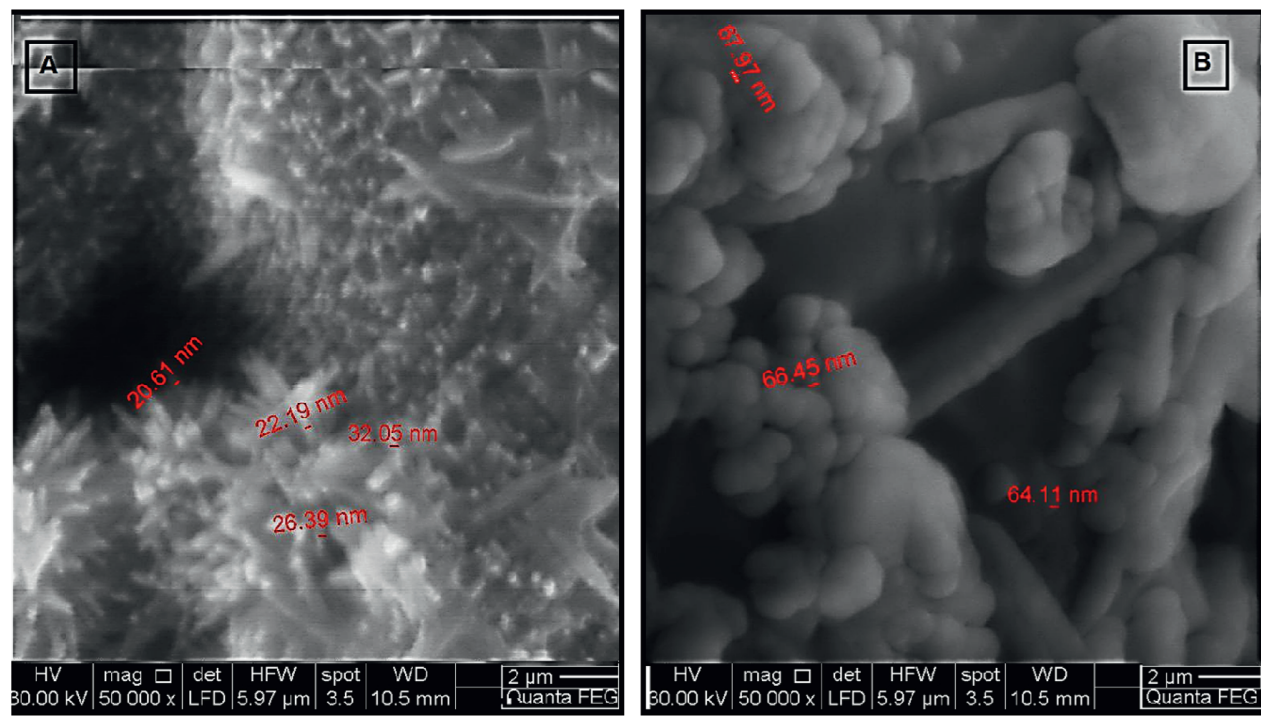

Figure 2: The SEM micrographs of (a) Cd(II)- $\mathrm{H}_{2} \mathrm{~L}$ and (b) $\mathrm{H}_{2} \mathrm{~L}$.

TABLE 1: The mean contact angle of $\mathrm{H}_{2} \mathrm{~L}$ and its complexes.

\begin{tabular}{lccc}
\hline Compound & Mean contact angle $\left(^{\circ}\right)$ & Wettability classification & Surface morphology \\
\hline$\left[\mathrm{Cr}\left(\mathrm{H}_{2} \mathrm{~L}\right) \mathrm{Cl}_{2}\right] \mathrm{Cl} \cdot 2 \mathrm{H}_{2} \mathrm{O}$ & 137 & Hydrophobic & Rough and porous \\
{$\left[\mathrm{Mn}\left(\mathrm{H}_{2} \mathrm{~L}\right) \mathrm{Cl}_{2}\right]$} & 128 & Hydrophobic & Rough and porous \\
{$\left[\mathrm{Fe}\left(\mathrm{H}_{2} \mathrm{~L}\right) \mathrm{Cl}_{2}\right] \mathrm{Cl}_{2} \mathrm{H}_{2} \mathrm{O}$} & 142 & Hydrophobic & Rough and porous \\
{$\left[\mathrm{Co}\left(\mathrm{H}_{2} \mathrm{~L}\right) \mathrm{Cl}_{2}\right]$} & 123 & Hydrophobic & Rough and porous \\
{$\left[\mathrm{Ni}_{2}\left(\mathrm{H}_{2} \mathrm{~L}\right) \mathrm{Cl}_{2}\right]$} & 132 & Hydrophobic & Rough and porous \\
{$\left[\mathrm{Cu}\left(\mathrm{H}_{2} \mathrm{~L}\right) \mathrm{Cl}_{2}\right] \cdot 3 / 2 \mathrm{H}_{2} \mathrm{O}$} & 133 & Hydrophobic & Rough and porous \\
{$\left[\mathrm{Zn}\left(\mathrm{H}_{2} \mathrm{~L}\right) \mathrm{Cl}_{2}\right] \cdot \mathrm{H}_{2} \mathrm{O}$} & 128 & Hydrophobic & Rough and porous \\
{$\left[\mathrm{Cd}\left(\mathrm{H}_{2} \mathrm{~L}\right) \mathrm{Cl}_{2}\right] \cdot \mathrm{H}_{2} \mathrm{O}$} & 153 & Superhydrophobic & Very rough and very porous \\
$\mathrm{H}_{2} \mathrm{~L}$ azo dye ligand & 103 & Hydrophobic & Rough and porous \\
\hline
\end{tabular}

TABLe 2: Thermoanalytical results (TG and DTG) of the $\mathrm{H}_{2} \mathrm{~L}$ ligand and its metal complexes.

\begin{tabular}{|c|c|c|c|c|c|c|}
\hline Complex & $\begin{array}{l}\text { TG range } \\
\left({ }^{\circ} \mathrm{C}\right)\end{array}$ & DTG max & $n^{*}$ & $\begin{array}{c}\text { Mass loss estim (calcd)\% (total } \\
\text { mass loss) }\end{array}$ & Assignment & Residues \\
\hline \multirow{2}{*}{ Diazo ligand $\left(\mathrm{H}_{2} \mathrm{~L}\right)$} & $30-355$ & 216 & 1 & $36.53(38.61)$ & \multirow{2}{*}{$\begin{array}{c}\text { Loss of } 4 \mathrm{NH}_{3} \text { and } 2 \mathrm{CO}_{2} \\
\text { Loss of } \mathrm{C}_{18} \mathrm{H}_{14} \mathrm{~N}_{2}\end{array}$} & \multirow[b]{2}{*}{ 一 } \\
\hline & $355-1000$ & 476,602 & 2 & $61.76(61.38) 100.0(99.90)$ & & \\
\hline \multirow{3}{*}{$\begin{array}{l}{\left[\mathrm{Cr}\left(\mathrm{H}_{2} \mathrm{~L}\right) \mathrm{Cl}_{2}\right]} \\
\mathrm{Cl} .2 \mathrm{H}_{2} \mathrm{O}\end{array}$} & $45-115$ & 79 & 1 & $8.88(8.53)$ & Loss of $2 \mathrm{H}_{2} \mathrm{O}$ and $\mathrm{NH}_{3}$ & \multirow{3}{*}{$1 / 2 \mathrm{Cr}_{2} \mathrm{O}_{3}$} \\
\hline & $115-310$ & 210 & 1 & $30.00(29.90)$ & Loss of $3 / 2 \mathrm{Cl}_{2}, 2 \mathrm{~N}_{2}$, and $\mathrm{CH}_{4}$ & \\
\hline & $310-990$ & 377,865 & 2 & $41.30(43.10) 80.18(81.53)$ & Loss of $\mathrm{C}_{17} \mathrm{H}_{12} \mathrm{NO}_{2.5}$ & \\
\hline \multirow{3}{*}[\mathrm{Mn}(\mathrm{H}_{2}\mathrm{L})\mathrm{Cl}_{2}]{} & $30-435$ & 234 & 1 & $58.98(58.86)$ & Loss of $2 \mathrm{~N}_{2}, \mathrm{Cl}_{2}$, and $\mathrm{C}_{9} \mathrm{H}_{5} \mathrm{~N}_{2}$ & \multirow{3}{*}{$7 \mathrm{C}+\mathrm{MnO}$} \\
\hline & $435-1000$ & 592 & 1 & 20.88 (20.18) $79.66(79.04)$ & Loss of $\mathrm{C}_{4} \mathrm{H}_{11} \mathrm{O}_{3}$ & \\
\hline & $45-100$ & 75 & 1 & $3.29(3.07)$ & Loss of $\mathrm{H}_{2} \mathrm{O}$ & \\
\hline \multirow[t]{2}{*}{$\begin{array}{l}{\left[\mathrm{Fe}\left(\mathrm{H}_{2} \mathrm{~L}\right) \mathrm{Cl}_{2}\right]} \\
\text { Cl. } \mathrm{H}_{2} \mathrm{O}\end{array}$} & $100-355$ & 244 & 1 & $47.89(48.33)$ & $\begin{array}{l}\text { Loss of } 3 / 2 \mathrm{Cl}_{2}, 3 \mathrm{~N}_{2}, 3 \mathrm{CH}_{4} \text {, and } \\
\qquad \mathrm{CO}_{2}\end{array}$ & \multirow[t]{2}{*}{$\begin{array}{l}5 \mathrm{C}+1 / \\
2 \mathrm{Fe}_{2} \mathrm{O}_{3}\end{array}$} \\
\hline & $355-1000$ & $485,565,803$ & 3 & $25.37(24.63) 76.62(76.03)$ & Loss of $\mathrm{C}_{11} \mathrm{H}_{4} \mathrm{O}_{0.5}$ & \\
\hline \multirow{3}{*}[\mathrm{Co}(\mathrm{H}_{2}\mathrm{L})\mathrm{Cl}_{2}]{} & $30-260$ & 177 & 1 & $12.23(12.45)$ & Loss of $2 \mathrm{NH}_{3}$ and $1 / 2 \mathrm{Cl}_{2}$ & \multirow{3}{*}{$2 \mathrm{C}+\mathrm{CoO}$} \\
\hline & $260-475$ & 364 & 1 & $6.33(6.64)$ & Loss of $1 / 2 \mathrm{Cl}_{2}$ & \\
\hline & $475-890$ & 640 & 1 & $60.3(60.03) 78.91$ (79.09) & Loss of $\mathrm{C}_{18} \mathrm{H}_{13} \mathrm{~N}_{5} \mathrm{O}$ & \\
\hline \multirow{2}{*}[\mathrm{Ni}(\mathrm{H}_{2}\mathrm{L})\mathrm{Cl}_{2}]{} & $40-290$ & 199 & 1 & $31.24(31.27)$ & Loss of $4 \mathrm{NH}_{3}, \mathrm{~N}_{2}$, and $\mathrm{Cl}_{2}$ & \multirow{2}{*}{$8 \mathrm{C}+\mathrm{NiO}$} \\
\hline & $290-970$ & 395,883 & 2 & $35.57(36.70) 67.85(67.95)$ & Loss of $\mathrm{C}_{12} \mathrm{H}_{4} \mathrm{O}_{3}$ & \\
\hline \multirow{3}{*}{$\begin{array}{l}{\left[\mathrm{Cu}\left(\mathrm{H}_{2} \mathrm{~L}\right) \mathrm{Cl}_{2}\right] .3 /} \\
2 \mathrm{H}_{2} \mathrm{O}\end{array}$} & $45-145$ & 88 & 1 & $4.71(4.77)$ & Loss of $3 / 2 \mathrm{H}_{2} \mathrm{O}$ & \multirow{3}{*}{$2 \mathrm{C}+\mathrm{CuO}$} \\
\hline & $145-990$ & 287 & 1 & $77.67(76.92) 82.38(81.70)$ & Loss of $\mathrm{C}_{18} \mathrm{H}_{16} \mathrm{Cl}_{2} \mathrm{~N}_{6} \mathrm{O}_{3}$ & \\
\hline & $45-130$ & 86 & 1 & $5.42(5.72)$ & Loss of $\mathrm{H}_{2} \mathrm{O}$ and $1 / 2 \mathrm{~N}_{2}$ & \\
\hline \multirow[t]{3}{*}[\mathrm{Zn}(\mathrm{H}_{2}\mathrm{L})\mathrm{Cl}_{2}]{$\cdot \mathrm{H}_{2} \mathrm{O}$} & $130-270$ & 205 & 1 & $10.36(10.26)$ & Loss of $2 \mathrm{~N}_{2}$ & \multirow[t]{2}{*}{$3 \mathrm{C}+\mathrm{ZnO}$} \\
\hline & $270-1000$ & 348,467 & 2 & $63.4(63.20) 79.17$ (79.18) & Loss of $\mathrm{C}_{17} \mathrm{H}_{16} \mathrm{Cl}_{2} \mathrm{NO}_{3}$ & \\
\hline & $40-130$ & 98 & 1 & $2.95(2.90)$ & Loss of $\mathrm{H}_{2} \mathrm{O}$ & \multirow{3}{*}{$\mathrm{CdO}$} \\
\hline \multirow[t]{2}{*}[\mathrm{Cd}(\mathrm{H}_{2}\mathrm{L})\mathrm{Cl}_{2}]{$\cdot \mathrm{H}_{2} \mathrm{O}$} & $130-355$ & 222 & 1 & $25.63(25.62)$ & Loss of $3 \mathrm{~N}_{2}$ and $\mathrm{Cl}_{2}$ & \\
\hline & $355-1000$ & $414,591,833$ & 3 & $50.15(50.25) 78.73(78.77)$ & Loss of $\mathrm{C}_{20} \mathrm{H}_{16} \mathrm{O}_{3}$ & \\
\hline
\end{tabular}

$n^{*}=$ number of decomposition steps. 
contaminated with carbon as a final product. They were accompanied by a weight loss of $25.37 \%$ (calcd. $=24.63 \%$ ) and corresponded to the loss of the $\mathrm{C}_{11} \mathrm{H}_{4} \mathrm{O}_{0.5}$ molecule. The actual weight loss from these five steps was $76.62 \%$ which was close to the calculated value of $76.03 \%$.

The thermal degradation of the $\left[\mathrm{Co}\left(\mathrm{H}_{2} \mathrm{~L}\right) \mathrm{Cl}_{2}\right]$ complex took place in three degradation stages within the temperature range from 30 to $990^{\circ} \mathrm{C}$. The first stage of decomposition occurred at maximum $177^{\circ} \mathrm{C}$ and was accompanied by a weight loss of $12.23 \%$ (calcd. $=12.45 \%$ ) corresponding to the loss of $2 \mathrm{NH}_{3}$ and $1 / 2 \mathrm{Cl}_{2}$ gases. The second and third steps of decomposition occurred at two maxima 364 and $640^{\circ} \mathrm{C}$ and were accompanied by a weight loss of $6.33 \%$ (calcd. $=6.64 \%)$ and $60.30 \%($ calcd. $=60.03 \%)$, respectively, corresponding to the loss of $1 / 2 \mathrm{Cl}_{2}$ gas and $\mathrm{C}_{18} \mathrm{H}_{3} \mathrm{~N}_{5} \mathrm{O}$ molecule giving $\mathrm{CoO}$ contaminated with carbon as a final product. Theoretically, the weight loss in these steps was $78.91 \%$ which agrees with the experimental value of $79.09 \%$.

The $\left[\mathrm{Ni}\left(\mathrm{H}_{2} \mathrm{~L}\right) \mathrm{Cl}_{2}\right]$ complex lost upon heating $4 \mathrm{NH}_{3}, \mathrm{Cl}_{2}$, and $\mathrm{N}_{2}$ gases in the first step of decomposition within the temperature range of $40-290^{\circ} \mathrm{C}$. The last two steps of decomposition occurred at two maxima at 395 and $880^{\circ} \mathrm{C}$. These steps were associated with the loss of the $\mathrm{C}_{12} \mathrm{H}_{4} \mathrm{O}_{3}$ molecule forming $\mathrm{NiO}$ contaminated with carbon as a final product. The actual total weight loss of $67.85 \%$ was in agreement with the calculated total weight loss value of $67.95 \%$.

The complex $\left[\mathrm{Cu}\left(\mathrm{H}_{2} \mathrm{~L}\right) \mathrm{Cl}_{2}\right] \cdot 3 / 2 \mathrm{H}_{2} \mathrm{O}$ lost upon heating all water molecules at one maxima $90^{\circ} \mathrm{C}$ with an estimated weight loss of $4.70 \%$ (calcd. $=4.77 \%$ ). The dehydrated $\mathrm{Cu}(\mathrm{II})$ complex was simultaneously decomposed to $\mathrm{CuO}$ and $2 \mathrm{C}$ at the $287^{\circ} \mathrm{C}$ maximum temperature. The total weight loss amounted to $82.38 \%$ (calcd. $=81.74 \%$ ).

The $\left[\mathrm{Zn}\left(\mathrm{H}_{2} \mathrm{~L}\right) \mathrm{Cl}_{2}\right] \cdot \mathrm{H}_{2} \mathrm{O}$ complex was thermally decomposed into four steps within the temperature range from 45 to $1000^{\circ} \mathrm{C}$. The first decomposition step with an estimated mass loss of $5.42 \%$ (calcd. $=5.72 \%$ ) occurred within the temperature range from 45 to $130^{\circ} \mathrm{C}$. This step may be attributed to the liberation of the hydrated water molecules and $\mathrm{NH}_{3}$ gas. The remaining three decomposition steps of the $\mathrm{Zn}$ (II) complex were observed within the temperature range from 130 to $1000^{\circ} \mathrm{C}$. Estimated mass losses of $73.76 \%$ (calcd. $=74.42 \%$ ) were reasonably accounted for the removal of two $2 \mathrm{~N}_{2}$ gases and a $\mathrm{C}_{17} \mathrm{H}_{16} \mathrm{Cl}_{2} \mathrm{NO}_{3}$ molecule in two steps.

TG curve of the $\left[\mathrm{Cd}\left(\mathrm{H}_{2} \mathrm{~L}\right) \mathrm{Cl}_{2}\right] \cdot \mathrm{H}_{2} \mathrm{O}$ complex displayed a five-step decomposition. The first step of decomposition occurred within the temperature range from 40 to $130^{\circ} \mathrm{C}$, with a maximum temperature at $98^{\circ} \mathrm{C}$, and corresponded to the loss of one water molecule of hydration. The second step of decomposition occurred in the range of $130-355^{\circ} \mathrm{C}$, with one maxima at $222^{\circ} \mathrm{C}$, and corresponded to the elimination of $\mathrm{Cl}_{2}$ and $3 \mathrm{~N}_{2}$ gases with a mass loss of $25.62 \%$ (calcd. $=25.63 \%$ ). The last three steps of decomposition occurred within the temperature range of $355-1000^{\circ} \mathrm{C}$ with three maxima at 414,591 , and $833^{\circ} \mathrm{C}$ and were simultaneously decomposed to $\mathrm{CdO}$ as a final product. They were accompanied by a weight loss of $50.25 \%$ (calcd. $=50.15 \%$ ) corresponding to the loss of the $\mathrm{C}_{20} \mathrm{H}_{16} \mathrm{O}_{3}$ molecule. The weight loss from these five steps was $78.77 \%$ which was close to the calculated value of $78.73 \%$.
3.3. Geometry Optimization. The geometric parameters (bond lengths and bond angles) of the optimized structures of the $\mathrm{H}_{2} \mathrm{~L}$ azo ligand and its $\mathrm{Cd}$ (II) complex (Figure 3 ) are listed in Supplementary Table 5. From the analysis of these data, the following remarks were found:

(1) There was an elongation in the coordination bonds after complexation, and a large variation in $\mathrm{N}(11)$ $\mathrm{N}(14), \mathrm{N}(12)-\mathrm{N}(13), \mathrm{O}(35)-\mathrm{H}(40)$, and $\mathrm{O}(38)-\mathrm{H}(39)$ bond lengths of the ligand occurred upon complexation. It became slightly longer confirming that the coordination took place via azo $\mathrm{N}$ atoms and protonated $\mathrm{O}$ groups.

(2) All the active groups taking part in coordination have bonds longer than those already existed in the ligands (for example, $\mathrm{N}=\mathrm{N}$ ).

(3) The bond angles of the free ligand moiety were altered somewhat upon coordination; also, the bond angles surrounding the central cadmium atom in the complex lie in the range reported for octahedral geometry [43].

(4) The decrease in the metal-chloride angles may be attributed to the intramolecular hydrogen bond [43].

3.4. Molecular Electrostatic Potential (MEP). The MEP is a plot of electrostatic potential mapped onto the constant electron density surface. It is also very useful in the research of the molecular structure with its physiochemical property relationship. It is also can be used to understand the molecular interactions and predict the reactive sites for electrophilic and nucleophilic attacks [43]. The MEP is directly related to chemical reactivity. Red color represented the regions of negative electrostatic potential. The negative regions are related to electrophilic reactivity. However, the electron-poor region has blue color (favor site for the nucleophilic attack) [43, 44], but the region with green color points to the neutral electrostatic potential region. Figure 4 represents 3D plots of the MEP for the parent ligand and its $\mathrm{Cd}(\mathrm{II})$ complex. It was found that oxygen and nitrogen atoms of free $\mathrm{H}_{2} \mathrm{~L}$ were surrounded by a greater negative charge surface, making these sites potentially more favorable for the electrophilic attack (Figure 4(a)), where a greater negative charge was surrounded to the metal center (Figure 4(b)) confirming the complexation process.

3.5. Mulliken Charges. Supplementary Table 6 and Supplementary Figure 6 clarify Mulliken atomic charges for some important atoms. The calculated charge value for N13 and N14 is -0.08 and -0.007 a.u., respectively, in contrast to the expected one ( -1 a.u.), which indicated electron transfer from these atoms to the metal center. Furthermore, decrease of oxygen and chlorine formal charge from the expected values is a reason for migration of electrons to the cadmium center in order to forming the complex. Finally, this charge transfer from donor atoms to the metal center causes the calculated value to decrease to -0.756 a.u. against the formal charge of +2 for the cadmium atom $[43,44]$. 


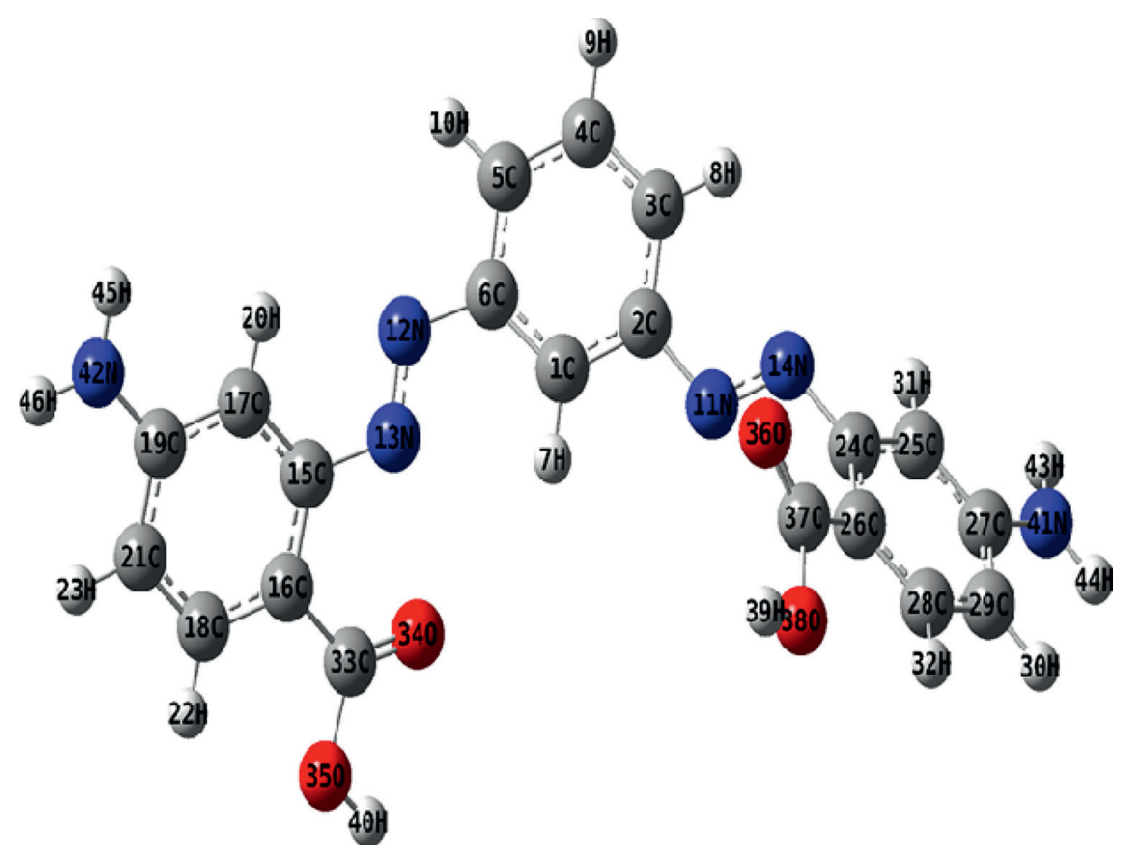

(a)

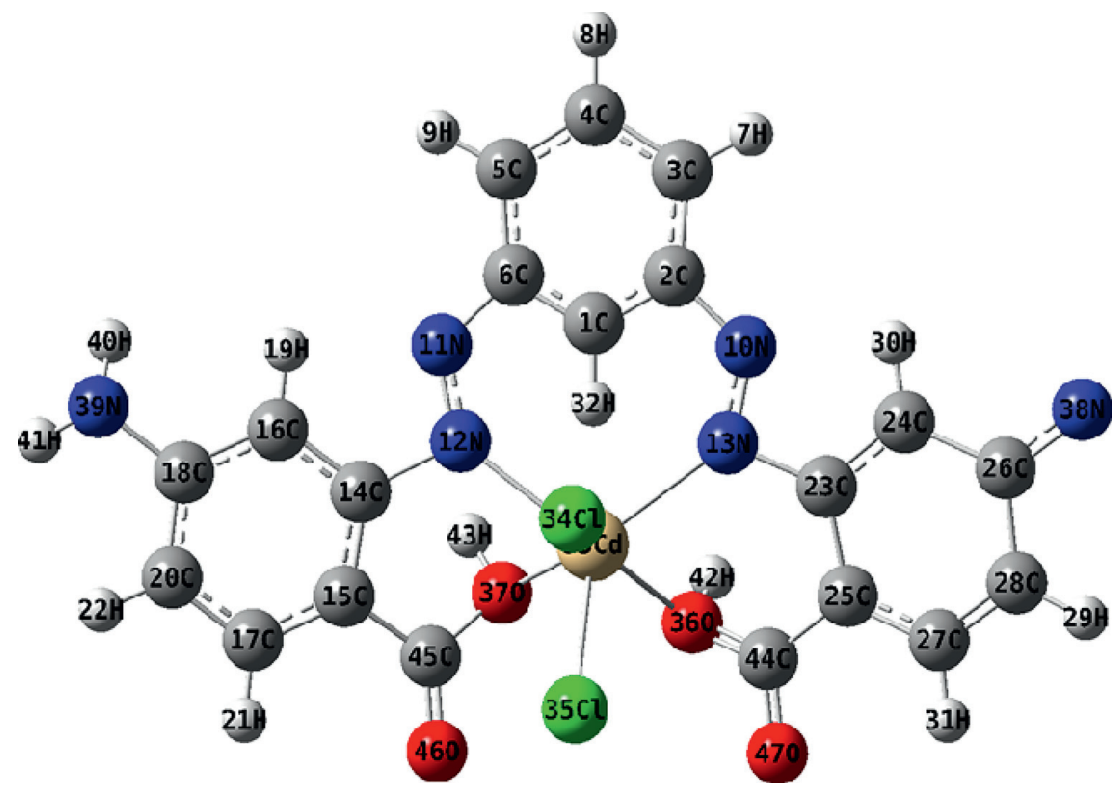

(b)

Figure 3: The optimized structure of (a) $\mathrm{H}_{2} \mathrm{~L}$ and (b) $\left[\mathrm{Cd}\left(\mathrm{H}_{2} \mathrm{~L}\right) \mathrm{Cl}_{2}\right] \cdot \mathrm{H}_{2} \mathrm{O}$.

3.6. Molecular Parameters. Figure 5 shows the molecular orbital representation of the $\mathrm{H}_{2} \mathrm{~L}$ ligand and its $\mathrm{Cd}(\mathrm{II})$ complex along with their HOMO, LUMO energies and energy band gaps. Both the highest occupied molecular orbital (HOMO) and lowest unoccupied molecular orbital (LUMO) were the main orbitals that participate in chemical stability $[11,44,45]$. The HOMO represented the ability to donate an electron; LUMO as an electron acceptor represents the ability to obtain an electron. In other words, the energy of the HOMO is directly related to the ionization potential; LUMO energy is directly related to the electron affinity. Hence, these frontier energies play an important role in the electric and optical properties. The energy gap between the HOMO and LUMO energies is a critical parameter in determining molecular electrical transport properties due to providing measurement of electron conductivity. In addition, this energy gap characterizes the molecular stability and spectroscopic properties of the molecular systems. The smaller energy gap describes a chemically soft molecule which can be easily polarizable. The HOMO-LUMO energy gap has proved to be an important tool in determining the kinetic stability and chemical reactivity of a molecule. The lower energy gap is a suitable condition where a molecule can be exited easily, whereas a 
higher energy gap leads to higher kinetic stability but lower chemical reactivity of the molecule. The difference between the energy gap for the ligand reflects the presence of the complexation status. The increase in the global electrophilicity value attributed to the highest capacity of accepted electrons, so the ligand has a highly powerful donation ability. The calculation of both absolute hardness $(\eta)$ and absolute softness $(\sigma)$ parameters is useful to recognize the molecular stability and reactivity. The calculations of the binding energy indicated that the increase of the value of the calculated binding energy of the complex compared to that of the free ligand indicated that the stability of the formed Cd(II) complex was higher than that of the free diazo ligand.

Additional parameters such as chemical potentials $P i$, global electrophilicity $\omega$, global softness $S$, electrophilicity index $(\chi)$, and additional electronic charge $\Delta N_{\max }$ were calculated for the free $\mathrm{H}_{2} \mathrm{~L}$ ligand and the $\mathrm{Cd}-\mathrm{H}_{2} \mathrm{~L}$ complex (Table 3). The high $\omega$ value of both free $\mathrm{H}_{2} \mathrm{~L}$ and $\mathrm{Cd}(\mathrm{II})$ complex suggested a great chance and priority for biological activity which is further confirmed by the experimental data.

The mentioned quantum chemical parameters were calculated with the help of the following equations $[43,44]$ :

$$
\begin{aligned}
\Delta E & =E_{\mathrm{LUMO}}-E_{\mathrm{HOMO}}, \\
\chi & =\frac{-\left(E_{\mathrm{HOMO}}+E_{\mathrm{LUMO}}\right)}{2}, \\
\eta & =\frac{E_{\mathrm{LUMO}}-E_{\mathrm{HOMO}}}{2}, \\
\sigma & =\frac{1}{\eta}, \\
P i & =-\chi, \\
S & =\frac{1}{2 \eta}, \\
\omega & =\frac{P i^{2}}{2 \eta}, \\
\Delta N_{\max } & =\frac{P i}{\eta} .
\end{aligned}
$$

3.7. Vibrational Properties. In order to acquire the spectroscopic signature of the diazo ligand and its complexes, a frequency calculation analysis was performed. Vibrational properties had been investigated to determine vibrational modes connected with the molecular structure of the cadmium (II) complex using FT-IR spectra based on the optimized geometry. It is well known that the vibrational frequencies computed at quantum chemical methods such as DFT levels contain well-known systematic errors. The scaling factor of 0.96 for the LanL2DZ level was used to correct the effects of anharmonicity and neglected part of electron correlation $[11,44,45]$. The theoretical and the experimental spectra are shown in Supplementary Figure 8.
It is also noteworthy that experimental results belong to the solid phase, while theoretical calculations belong to a gas phase.

The stretching vibration of a free or nonhydrogenbonded $\mathrm{OH}$ group of $\mathrm{H}_{2} \mathrm{~L}$ appears at $3664 \mathrm{~cm}^{-1}[11,45]$. $v\left(\mathrm{COO}^{-}\right)_{\text {asy }}$ and $v\left(\mathrm{COO}^{-}\right)_{\text {sy }}$ stretching of the free ligand appeared at $1597 \mathrm{~cm}^{-1}$ and $1392 \mathrm{~cm}^{-1}$, respectively. The theoretical spectrum of the free azo ligand showed $v \mathrm{NH}_{2}$ and $v \mathrm{~N}=\mathrm{N}$ modes at 3637 and $1694 \mathrm{~cm}^{-1}$, respectively. In the $\mathrm{Cd}$ (II) complex, the chelating ring occurred by means of the ligand bonding to the cadmium (II) ion with a tetradentate N,O chelated mode. It was observed from Figures 6 that the wavenumber interval between the $v\left(\mathrm{COO}^{-}\right)$asy and $v(\mathrm{COO}$ $\left.{ }^{-}\right)_{\text {sy }}$ stretching modes is an effective indicator of forming complexation. The wavenumber value of $v \mathrm{~N}=\mathrm{N}$ for the complex was lower than free $\mathrm{H}_{2} \mathrm{~L}$ which was an indicator of the coordination through the nitrogen atom. The spectrum of the $\mathrm{Cd}(\mathrm{II})$ complex showed $v \mathrm{NH}_{2}$ at a wave number very close to free $\mathrm{H}_{2} \mathrm{~L}$ at $3639 \mathrm{~cm}^{-1}$ confirming that this group did not participate in the complex formation process. $v \mathrm{M}-\mathrm{O}$, $v \mathrm{M}-\mathrm{N}$, and $v \mathrm{M}-\mathrm{Cl}$ modes of the $\mathrm{Cd}(\mathrm{II})$ complex were found at 564,487 , and $326 \mathrm{~cm}^{-1}$, respectively. The calculated and experimental data were very close to each other (Supplementary Figure 8).

3.8. Structural Interpretation of Metal Complexes. The structures of the complexes of the $\mathrm{H}_{2} \mathrm{~L}$ diazo ligand with $\mathrm{Cr}(\mathrm{III}), \mathrm{Mn}(\mathrm{II}), \mathrm{Fe}(\mathrm{III}), \mathrm{Co}(\mathrm{II}), \mathrm{Ni}(\mathrm{II}), \mathrm{Cu}(\mathrm{II}), \mathrm{Zn}(\mathrm{II})$, and $\mathrm{Cd}$ (II) ions were confirmed by the elemental analyses, IR, molar conductance, magnetic, mass, solid reflectance, and thermal analysis data. Therefore, from the IR spectra, it was concluded that $\mathrm{H}_{2} \mathrm{~L}$ behaved as a neutral tetradentate ligand coordinated to the metal ions via two nitrogen atoms of azo groups $(\mathrm{N}=\mathrm{N})$ and two oxygen atoms of protonated carboxylate groups (COO). From the molar conductance data, it was found that the complexes were electrolytes. On the basis of the above observations and from the magnetic and solid reflectance measurements, octahedral geometry was suggested for the investigated complexes (Figure 6).

\subsection{Antimicrobial Activity of Metal Complexes}

3.9.1. Antifungal Activities. The preliminary fungi toxicity screening of the $\mathrm{H}_{2} \mathrm{~L}$ diazo ligand and complexes was performed against Candida albicans in vitro by the diffusion technique [46]. $\mathrm{H}_{2} \mathrm{~L}$ free ligand and $\mathrm{Cr}(\mathrm{III}), \mathrm{Mn}(\mathrm{II})$, and $\mathrm{Fe}(\mathrm{III})$ complexes showed no fungal growth inhibition, but $\mathrm{Co}(\mathrm{II}), \mathrm{Ni}(\mathrm{II}), \mathrm{Cu}(\mathrm{II}), \mathrm{Zn}(\mathrm{II})$, and $\mathrm{Cd}(\mathrm{II})$ complexes showed fungal growth inhibition at different rates (Figure 7). The $\mathrm{Cd}(\mathrm{II})$ and $\mathrm{Ni}$ (II) complexes in this study were nearly two times more active than the ketokonazole standard against the Candida albicans microorganism used (Table 4).

3.9.2. Antibacterial Activities. The antibacterial activities of the $\mathrm{H}_{2} \mathrm{~L}$ diazo ligand and its complexes against Bacillus subtilis, Staphylococcus aureus, Neisseria gonorrhoeae, and Escherichia 


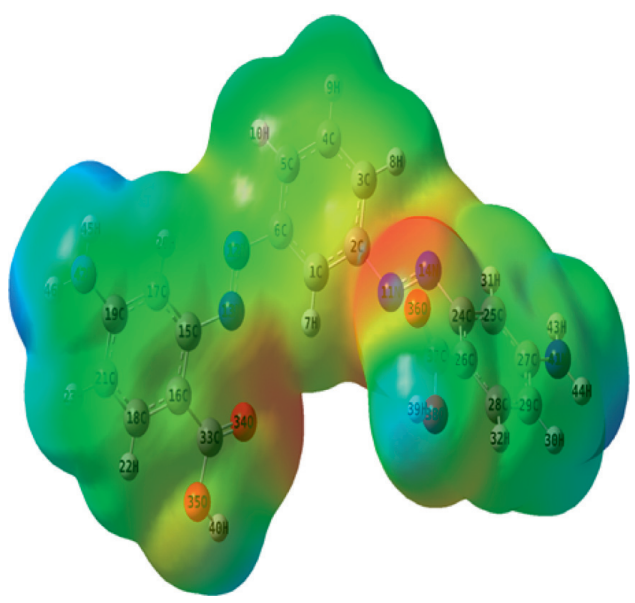

(a)

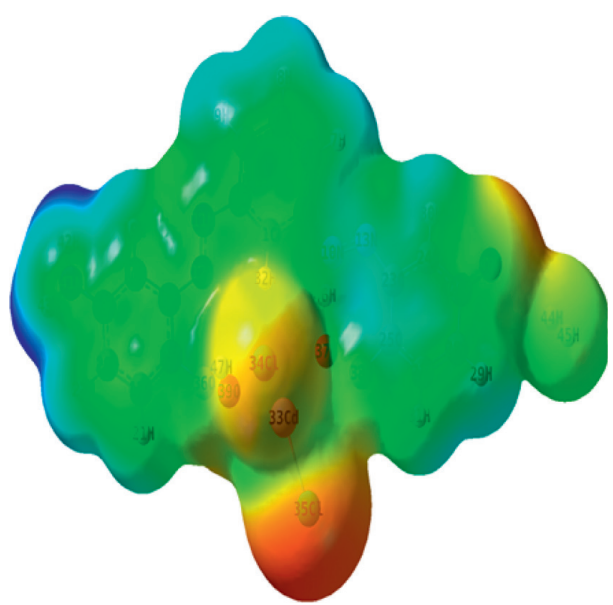

(b)

FIgURE 4: Molecular electrostatic potential map of (a) $\mathrm{H}_{2} \mathrm{~L}$ and (b) $\left[\mathrm{Cd}\left(\mathrm{H}_{2} \mathrm{~L}\right) \mathrm{Cl}_{2}\right] \cdot \mathrm{H}_{2} \mathrm{O}$. The electron density isosurface is 0.004 a.u.

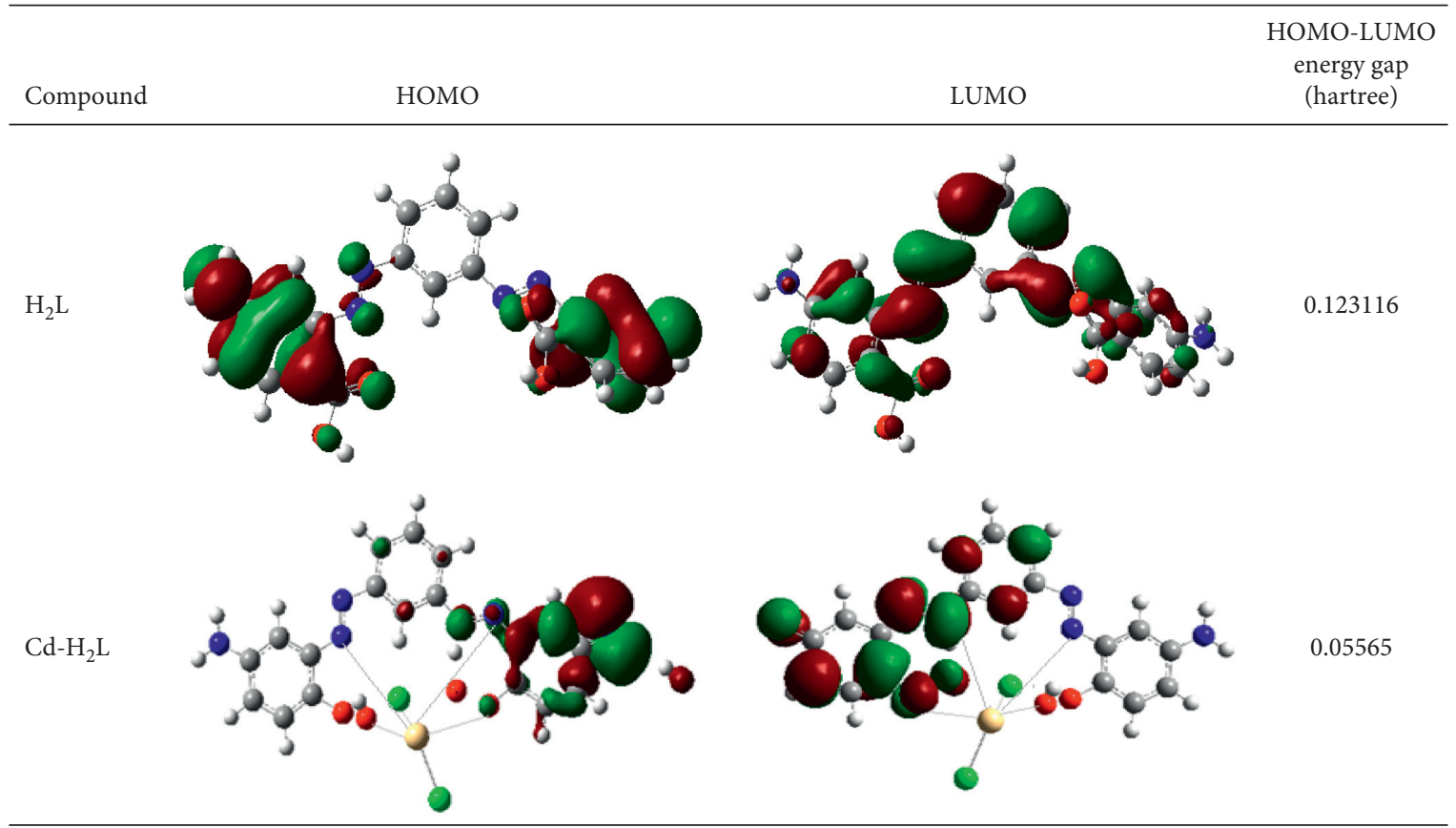

Figure 5: Surface phase of frontier orbitals of $\mathrm{H}_{2} \mathrm{~L}$ and $\left[\mathrm{Cd}\left(\mathrm{H}_{2} \mathrm{~L}\right) \mathrm{Cl}_{2}\right] . \mathrm{H}_{2} \mathrm{O}$.

coli are presented in Table 4. The $\mathrm{H}_{2} \mathrm{~L}$ ligand was found to have no activity at all towards both different types of bacteria (Grampositive Bacillus subtilis and Staphylococcus aureus and Gramnegative Neisseria gonorrhoeae and Escherichia coli). This can be attributed to their very versatile nutritional capability, adaptability to various hydrocarbon rings, and the possession of the pump mechanism which ejects metal complexes as soon as they enter the cell [47]. In addition, Bacillus subtilis, Staphylococcus aureus, Neisseria gonorrhoeae, and Escherichia coli were sensitive to all the complexes, and an inhibitory zone was obtained in the range of 9.0-23.0 $\mathrm{mm}$ (Figure 7).

In all cases, the metal complexes were found to be more active than the $\mathrm{H}_{2} \mathrm{~L}$ ligand expectedly due to chelation, which reduced the polarity of the metal atom, mainly
TABLE 3: The calculated quantum chemical parameters of $\mathrm{H}_{2} \mathrm{~L}$ and its Cd(II) complex.

\begin{tabular}{lcc}
\hline The quantum parameter & $\mathrm{H}_{2} \mathrm{~L}$ & {$\left[\mathrm{Cd}\left(\mathrm{H}_{2} \mathrm{~L}\right) \mathrm{Cl}_{2}\right] \cdot \mathrm{H}_{2} \mathrm{O}$} \\
\hline $\mathrm{E}$ (a.u.) & -1402.46 & -140.88 \\
Dipole moment (Debye) & 1.37 & 18.022 \\
$\mathrm{E}_{\mathrm{HOMO}}(\mathrm{eV})$ & -6.095 & -5.61 \\
$\mathrm{E}_{\mathrm{LUMO}}(\mathrm{eV})$ & -2.977 & -4.096 \\
$\Delta E(\mathrm{eV})$ & 3.349 & 1.508 \\
$\chi(\mathrm{eV})$ & 4.534 & 4.853 \\
$\eta(\mathrm{eV})$ & 1.559 & 0.757 \\
$\sigma(\mathrm{eV})^{-1}$ & 0.641 & 1.321 \\
$P i(\mathrm{eV})$ & -4.534 & -4.853 \\
$S(\mathrm{eV})^{-1}$ & 0.321 & 0.661 \\
$\omega(\mathrm{eV})$ & 6.593 & 15.559 \\
$\Delta N_{\max }$ & 2.9 & 6.412 \\
\hline & &
\end{tabular}




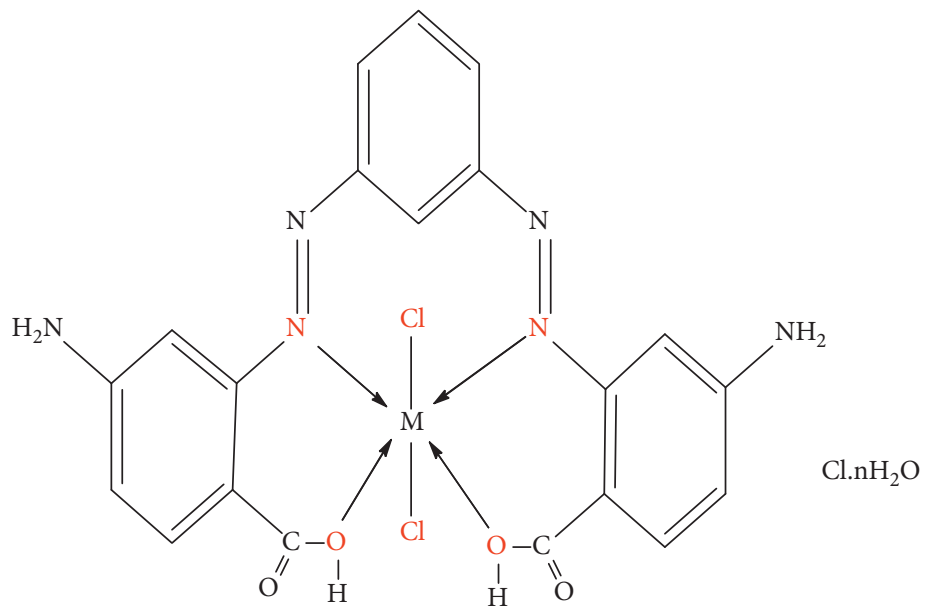

In case of $\mathrm{Cr}$ (III) and $\mathrm{Fe}(\mathrm{III})$ complexes (where $n=2$ for $\mathrm{Cr}$ (III) complex and $n=1$ for Fe(III) complex)

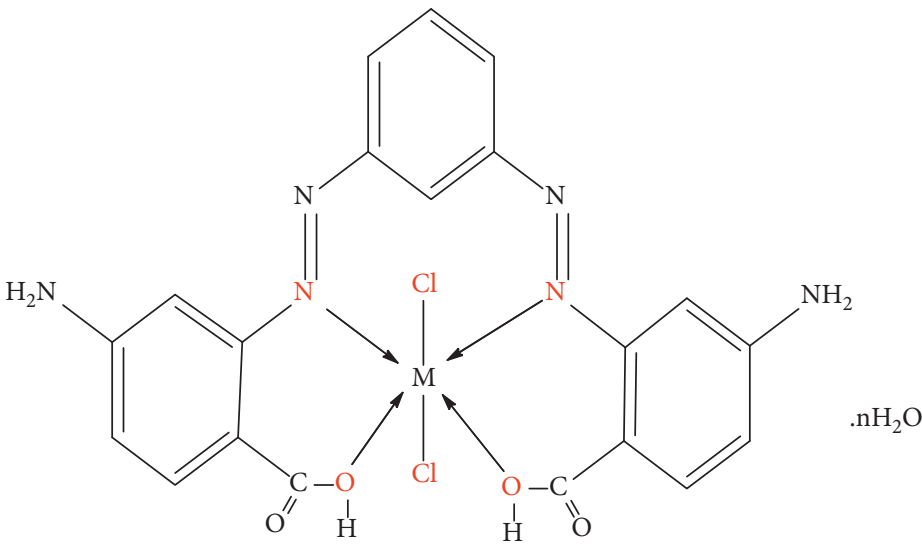

In case of $\mathrm{Mn}(\mathrm{II}), \mathrm{Co}(\mathrm{II}), \mathrm{Ni}(\mathrm{II}), \mathrm{Cu}(\mathrm{II}), \mathrm{Zn}(\mathrm{II})$ and $\mathrm{Cd}(\mathrm{II})$ complexes (where $n=1$ for $\mathrm{Cd}(\mathrm{II})$ and $\mathrm{Zn}(\mathrm{II})$ complexes, $n=1.5$ for $\mathrm{Cu}(\mathrm{II})$ complex and $n=0$ for $\mathrm{Mn}(\mathrm{II}), \mathrm{Co}(\mathrm{II})$, and $\mathrm{Ni}(\mathrm{II})$ )

Figure 6: The proposed structures of $\mathrm{H}_{2} \mathrm{~L}$ and its complexes.

because of partial sharing of its positive charge with donor groups of the ligand and possible $\pi$-electron delocalization on the aromatic rings. This increased the lipophilic character, favouring its permeation into the bacterial membrane, causing the death of the organisms [48].

Higher activity of the metal complex was probably due to greater lipophilic nature of the complex. It increased the activity of the metal complex and can be explained on the basis of Overtone's concept and Tweedy's chelation theory [49-52]. According to Overtone's concept of cell permeability, the lipid membrane that surrounds the cell favours the passage of only lipid-soluble materials due to which liposolubility was considered to be an important factor that controls the antimicrobial activity. On chelation, the polarity of the metal ion will be reduced to a greater extent due to the overlap of the ligand orbital and partial sharing of the positive charge of the metal ion with donor groups $[53,54]$. Furthermore, it increased the delocalization of the $\pi$ electrons over the whole chelate ring and enhanced the lipophilicity of the complex. This increased lipophilicity enhanced the penetration of the complexes into the lipid membrane and thus blocked the metal-binding sites on enzymes of microorganisms [55]. These metal complexes

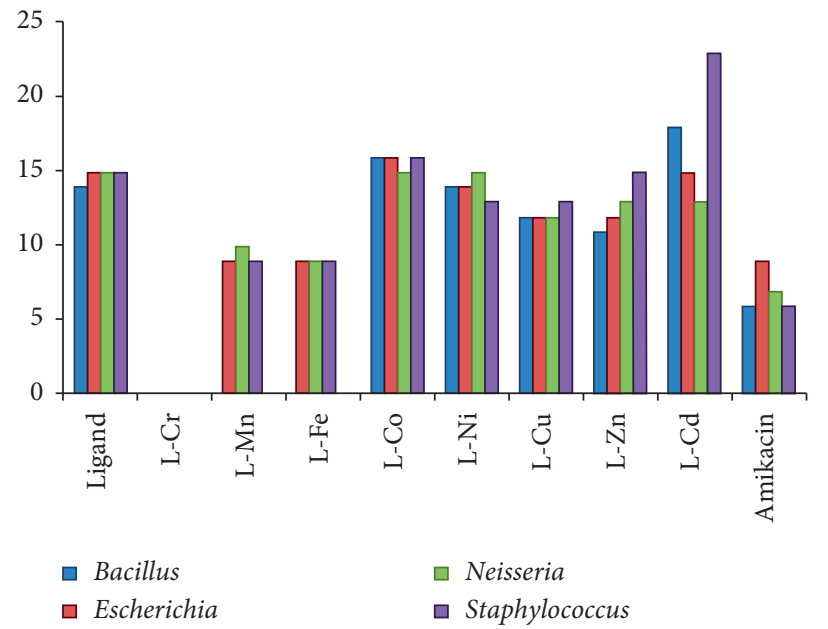

Figure 7: Biological activity of $\mathrm{H}_{2} \mathrm{~L}$ and its complexes.

also disturb the respiration process of the cell and thus block the synthesis of proteins, which restricts further growth of the organism [56]. 
TABLE 4: Biological activity of the $\mathrm{H}_{2} \mathrm{~L}$ ligand and its metal complexes.

\begin{tabular}{|c|c|c|c|c|c|}
\hline \multirow{2}{*}{ Sample } & \multicolumn{5}{|c|}{ Inhibition zone diameter ( $\mathrm{mm} / \mathrm{mg}$ sample) } \\
\hline & Bacillus subtilis & Escherichia coli & Neisseria gonorrhoeae & Staphylococcus aureus & Candida albicans \\
\hline Control: DMSO & 0.0 & 0.0 & 0.0 & 0.0 & 0.0 \\
\hline Ligand $\left(\mathrm{H}_{2} \mathrm{~L}\right)$ & 0.0 & 0.0 & 0.0 & 0.0 & 0.0 \\
\hline$\left[\mathrm{Cr}\left(\mathrm{H}_{2} \mathrm{~L}\right) \mathrm{Cl}_{2}\right] \mathrm{Cl} \cdot 2 \mathrm{H}_{2} \mathrm{O}$ & 14 & 15 & 15 & 15 & 0.0 \\
\hline$\left[\mathrm{Mn}\left(\mathrm{H}_{2} \mathrm{~L}\right) \mathrm{Cl}_{2}\right]$ & 9 & 10 & 9 & 0.0 & 0.0 \\
\hline$\left[\mathrm{Fe}\left(\mathrm{H}_{2} \mathrm{~L}\right) \mathrm{Cl}_{2}\right] \mathrm{Cl} \cdot \mathrm{H}_{2} \mathrm{O}$ & 9 & 9 & 9 & 0.0 & 0.0 \\
\hline$\left[\mathrm{Co}\left(\mathrm{H}_{2} \mathrm{~L}\right) \mathrm{Cl}_{2}\right]$ & 16 & 16 & 15 & 16 & 12 \\
\hline$\left[\mathrm{Ni}\left(\mathrm{H}_{2} \mathrm{~L}\right) \mathrm{Cl}_{2}\right]$ & 14 & 14 & 15 & 13 & 16 \\
\hline$\left[\mathrm{Cu}\left(\mathrm{H}_{2} \mathrm{~L}\right) \mathrm{Cl}_{2}\right] \cdot 3 / 2 \mathrm{H}_{2} \mathrm{O}$ & 12 & 12 & 12 & 13 & 10 \\
\hline$\left[\mathrm{Zn}\left(\mathrm{H}_{2} \mathrm{~L}\right) \mathrm{Cl}_{2}\right] \cdot \mathrm{H}_{2} \mathrm{O}$ & 11 & 12 & 13 & 15 & 9 \\
\hline$\left[\mathrm{Cd}\left(\mathrm{H}_{2} \mathrm{~L}\right) \mathrm{Cl}_{2}\right] \cdot \mathrm{H}_{2} \mathrm{O}$ & 18 & 15 & 13 & 23 & 17 \\
\hline Amikacin & 6 & 9 & 7 & 6 & 0 \\
\hline Ketokonazole & - & - & - & - & 9 \\
\hline
\end{tabular}

TABLE 5: Energy values obtained in docking calculations of $\mathrm{H}_{2} \mathrm{~L}$ with receptors of the crystal structure of S. aureus (PDB ID: 3Q8U), crystal structure of protein phosphatase (PPZ1) of Candida albicans (PDB ID: 5JPE), receptors of breast cancer mutant oxidoreductase (PDB ID: 3HB5), and crystal structure of Escherichia coli (PDB ID: 3T88).

\begin{tabular}{|c|c|c|c|c|c|}
\hline Receptor & Ligand moiety & Receptor & Interaction & Distance & $\mathrm{E}(\mathrm{kcal} / \mathrm{mol})$ \\
\hline \multirow{5}{*}{$5 \mathrm{JPE}$} & $\mathrm{N} 41$ & O HIS $413(\mathrm{~A})$ & H-donor & 3.07 & -2.5 \\
\hline & N 14 & NE2 HIS 290 (A) & $\mathrm{H}$-acceptor & 3.33 & -2.3 \\
\hline & O 34 & NH2 ARG 386 (A) & $\mathrm{H}$-acceptor & 3.01 & -2.8 \\
\hline & O 36 & NH2 ARG 261 (A) & $\mathrm{H}$-acceptor & 2.93 & -1.4 \\
\hline & O 36 & NE2 HIS 290 (A) & $\mathrm{H}$-acceptor & 2.99 & -1.1 \\
\hline \multirow{4}{*}{ 3HB5 } & $\mathrm{N} 41$ & OD1 ASN 152(X) & H-donor & 2.83 & -3.1 \\
\hline & $\mathrm{N} 42$ & O GLY $9(X)$ & H-donor & 3.44 & -0.7 \\
\hline & O 36 & OG SER $142(\mathrm{X})$ & $\mathrm{H}$-acceptor & 2.87 & -1.5 \\
\hline & 6-ring & CD2 PHE 192(X) & Pi-H & 3.75 & -0.6 \\
\hline \multirow{6}{*}{$3 \mathrm{Q} 8 \mathrm{U}$} & O 38 & OE1 GLU 95 (A) & H-donor & 2.90 & -6.0 \\
\hline & $\mathrm{N} 42$ & OE2 GLU 51 (A) & H-donor & 3.00 & -2.0 \\
\hline & N 14 & N THR 91 (A) & $\mathrm{H}$-acceptor & 3.54 & -1.6 \\
\hline & O 34 & NZ LYS 9 (A) & $\mathrm{H}$-acceptor & 3.58 & -0.6 \\
\hline & O 34 & NH2 ARG 102 (A) & $\mathrm{H}$-acceptor & 3.04 & -2.9 \\
\hline & O 38 & OE1 GLU 95 (A) & H-donor & 2.90 & -6.0 \\
\hline \multirow{4}{*}{$3 \mathrm{~T} 88$} & O 38 & O PHE 162 (A) & H-donor & 3.33 & -0.6 \\
\hline & $\mathrm{N} 41$ & OD2 ASP 163 (A) & H-donor & 3.11 & -2.2 \\
\hline & $\mathrm{N} 14$ & OH TYR $97(\mathrm{~A})$ & $\mathrm{H}$-acceptor & 3.18 & -1.2 \\
\hline & O 36 & OH TYR 97 (A) & $\mathrm{H}$-acceptor & 3.38 & -0.6 \\
\hline
\end{tabular}

TABLE 6: Energy values obtained in docking calculations of $\left[\mathrm{Cd}\left(\mathrm{H}_{2} \mathrm{~L}\right) \mathrm{Cl}_{2}\right] \cdot \mathrm{H}_{2} \mathrm{O}$ with receptors of the crystal structure of $S$. aureus (PDB ID: 3Q8U), crystal structure of protein phosphatase (PPZ1) of Candida albicans (PDB ID: 5JPE), receptors of breast cancer mutant oxidoreductase (PDB ID: 3HB5), and crystal structure of Escherichia coli (PDB ID: 3T88).

\begin{tabular}{|c|c|c|c|c|c|}
\hline Receptor & Ligand moiety & Receptor & Interaction & Distance & $\mathrm{E}(\mathrm{kcal} / \mathrm{mol})$ \\
\hline \multirow{4}{*}{$5 \mathrm{JPE}$} & $\mathrm{N} 42$ & OD2 ASP 373 (A) & H-donor & 2.89 & -3.1 \\
\hline & O 48 & O ARG 386 (A) & H-donor & 3.07 & -0.7 \\
\hline & O 38 & NH2 ARG 386 (A) & $\mathrm{H}$-acceptor & 3.16 & -2.4 \\
\hline & 6-ring & CE2 TYR 437 (A) & Pi-H & 4.62 & -0.6 \\
\hline \multirow{3}{*}{ 3HB5 } & $\mathrm{O} 48$ & O CYS 185 (X) & H-donor & 2.53 & -0.2 \\
\hline & O 48 & OG SER $142(\mathrm{X})$ & H-acceptor & 2.68 & -4.7 \\
\hline & 6-ring & CG1 VAL 225 (X) & Pi-H & 4.14 & -0.7 \\
\hline \multirow{8}{*}{$3 \mathrm{Q} 8 \mathrm{U}$} & N 10 & OE1 GLU 51 (A) & H-donor & 2.72 & -18 \\
\hline & N 10 & OE2 GLU 51 (A) & H-donor & 3.38 & -0.7 \\
\hline & CL 36 & O HIS 48 (A) & H-donor & 3.68 & -0.7 \\
\hline & $\mathrm{O} 48$ & O GLY $116(\mathrm{~A})$ & H-donor & 2.79 & -2.2 \\
\hline & O 50 & NH1 ARG 125 (A) & H-acceptor & 2.85 & -4.4 \\
\hline & N 10 & OE1 GLU 51 (A) & Ionic & 2.72 & -6.7 \\
\hline & N 10 & OE2 GLU 51 (A) & Ionic & 3.38 & -2.4 \\
\hline & N 10 & OD1 ASP 118 (A) & Ionic & 2.69 & -7.0 \\
\hline \multirow{2}{*}{$3 \mathrm{~T} 88$} & N 10 & O PHE $162(\mathrm{~A})$ & H-donor & 2.89 & -5.2 \\
\hline & O 38 & OH TYR 97 (A) & $\mathrm{H}$-acceptor & 2.68 & -2.0 \\
\hline
\end{tabular}




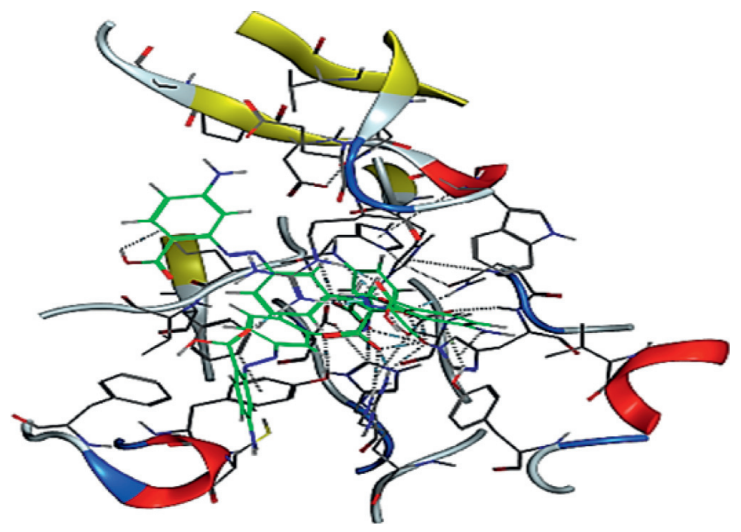

(a)

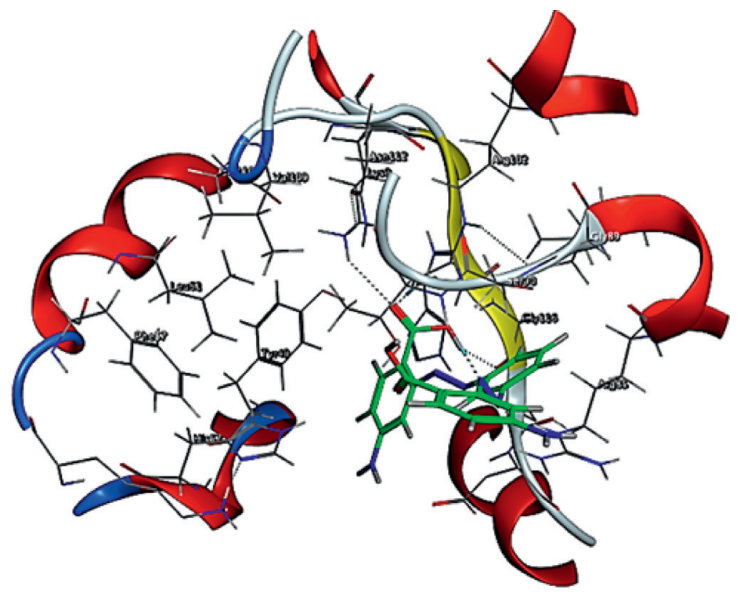

(c)

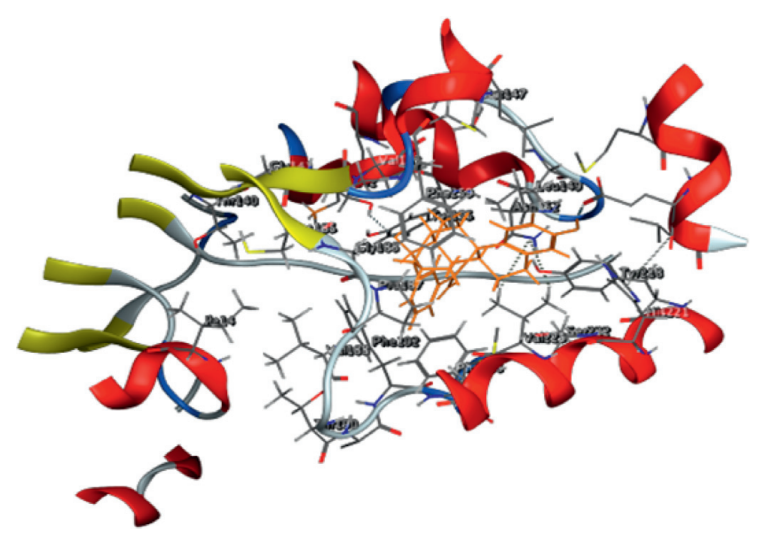

(b)

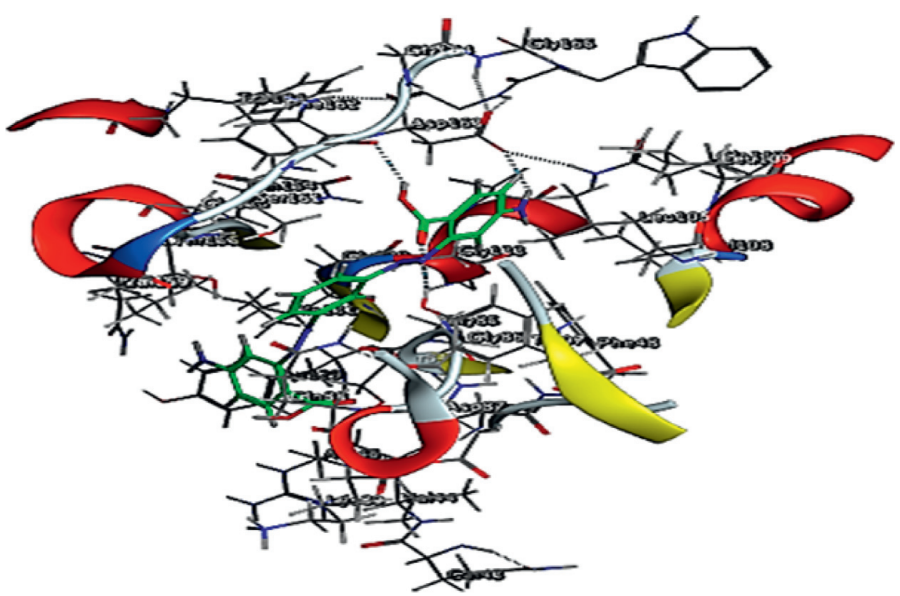

(d)

Figure 8: 3D plot of the interaction between the $\mathrm{H}_{2} \mathrm{~L}$ ligand with receptors of (a) 5JPE, (b) 3HB5, (c) 3Q8U, and (d) 3T88.

A look at the antibiotic, amikacin, activities $(6.0-9.0 \mathrm{~mm})$ against various bacterial isolates relative to the metal complexes $(9.0-23.0 \mathrm{~mm})$ showed that the activities of the former were much lower, with optimum activity being about half of metal complexes, against all the bacterial organisms.

When the antimicrobial activity of metal complexes is investigated, the following principal factors [57] should be considered: (i) the chelate effect of the ligands; (ii) the nature of the $\mathrm{N}$-donor ligands; (iii) the total charge of the complex; (iv) the existence and the nature of the ion neutralizing the ionic complex; and (v) the nuclearity of the metal center in the complex. This is probably one of the reasons for the diverse antibacterial activity shown by the complexes, while the nature of the metal ion coordinated to the $\mathrm{H}_{2} \mathrm{~L}$ ligand may have a significant role to this diversity. In general, all the complexes exhibited better inhibition than free $\mathrm{H}_{2} \mathrm{~L}$ against Bacillus subtilis, Staphylococcus aureus, Neisseria gonorrhoeae, and Escherichia coli (Table 4). More specifically, Cd(II) and $\mathrm{Co}$ (II) complexes showed the best inhibition among all the complexes in this study, and they were one to twentythree times more active than the $\mathrm{H}_{2} \mathrm{~L}$ diazo ligand against all the microorganisms used, indicating that the coordination of the $\mathrm{H}_{2} \mathrm{~L}$ ligand to $\mathrm{Cd}(\mathrm{II})$ and $\mathrm{Co}(\mathrm{II})$ ions enhanced its antimicrobial activity (Figure 7). On the contrary, the rest complexes present higher antimicrobial activity to $\mathrm{H}_{2} \mathrm{~L}$ against the four microorganisms.

3.10. Molecular Docking. Targeting the minor groove of DNA through binding to a small molecule has long been considered an important tool in molecular recognition of a specific DNA sequence. DNA is considered a major biological target for metal complexes that have pharmacological activity. In this context, molecular docking between $\mathrm{H}_{2} \mathrm{~L}$ and $\left[\mathrm{Cd}\left(\mathrm{H}_{2} \mathrm{~L}\right) \mathrm{Cl}_{2}\right] \cdot \mathrm{H}_{2} \mathrm{O}$ with four possible biological targets, receptors of the crystal structure of S. aureus (PDB ID: 3Q8U), crystal structure of protein phosphatase (PPZ1) of Candida albicans (PDB ID: 5JPE), receptors of breast cancer mutant oxidoreductase (PDB ID: 3HB5), and the crystal structure of Escherichia coli (PDB ID: 3T88), was performed. The structures of these macromolecules were obtained from the Protein Data Bank. The calculated binding energies for the interaction with these proteins are listed in Tables 5 and 6 . The 3D plot curves of docking with free $\mathrm{H}_{2} \mathrm{~L}$ and $\left[\mathrm{Cd}\left(\mathrm{H}_{2} \mathrm{~L}\right) \mathrm{Cl}_{2}\right] \cdot \mathrm{H}_{2} \mathrm{O}$ are shown in Figures 8 and 9.

From these data, the following can be concluded [58-60]:

(1) First, $\mathrm{H}_{2} \mathrm{~L}$ and its $\mathrm{Cd}(\mathrm{II})$ complex showed strong binding affinities for all proteins 


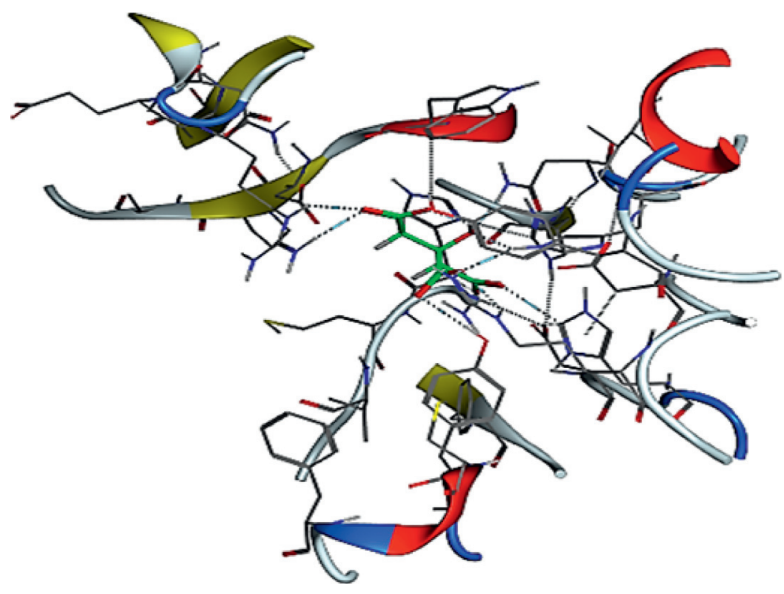

(a)

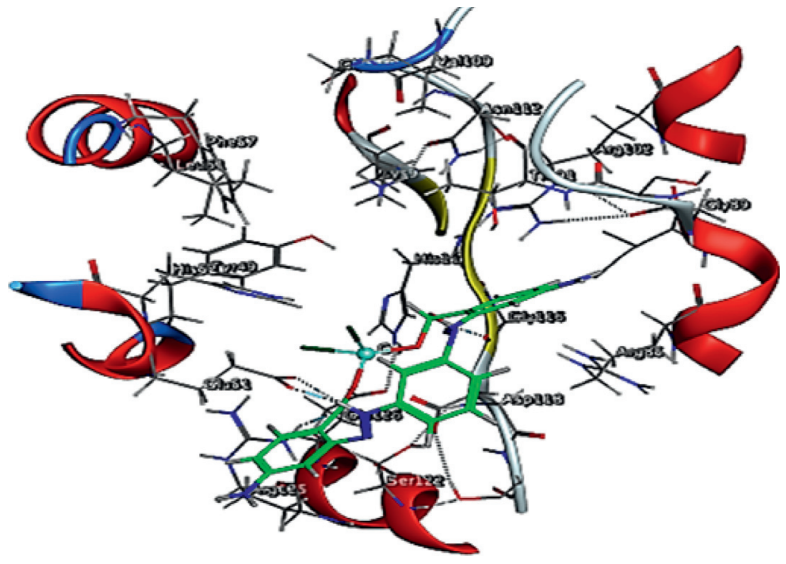

(c)

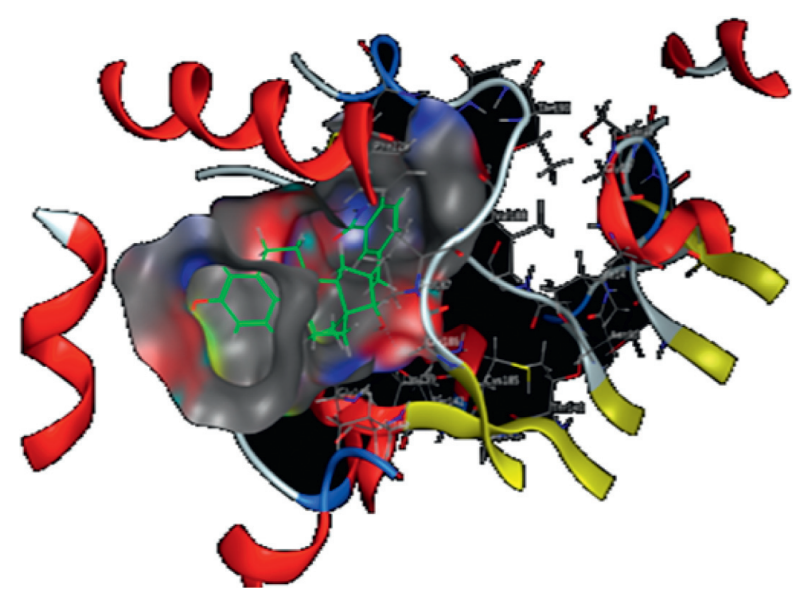

(b)

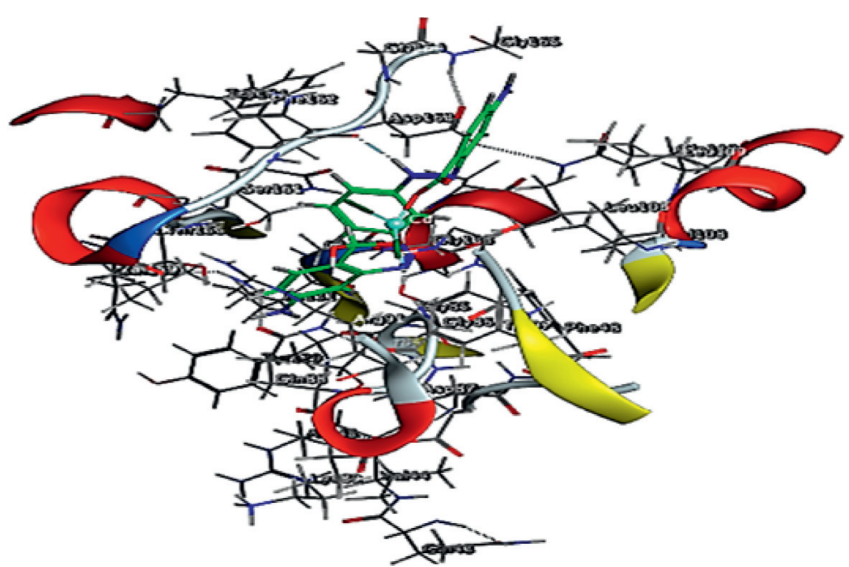

(d)

Figure 9: 3D plot of the interaction between $\mathrm{Cd}-\mathrm{H}_{2} \mathrm{~L}$ with receptors of (a) 5JPE, (b) 3HB5, (c) 3Q8U, and (d) $3 \mathrm{~T} 88$.

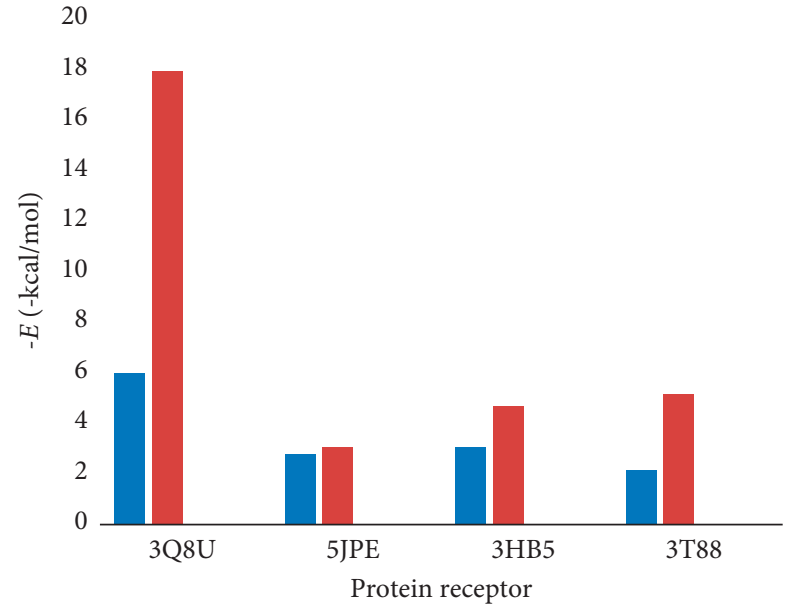

- $\mathrm{H}_{2} \mathrm{~L}$ ligand

- $\mathrm{Cd}-\mathrm{H}_{2} \mathrm{~L}$

FIGURE 10: The binding energy of the interaction between $\mathrm{H}_{2} \mathrm{~L}$ and $\mathrm{Cd}-\mathrm{H}_{2} \mathrm{~L}$ and receptors of 5JPE, 3HB5, 3Q8U, and 3T88.
(2) The $\left[\mathrm{Cd}\left(\mathrm{H}_{2} \mathrm{~L}\right) \mathrm{Cl}_{2}\right] \cdot \mathrm{H}_{2} \mathrm{O}$ complex binds stronger than the free ligand to different proteins, see Figure 10

(3) The binding energy for the interaction of the cadmium (II) complex with the receptor protein $3 \mathrm{Q} 8 \mathrm{U}$ was three times less than the free diazo ligand confirming the high activity of this compound [58]

(4) A closer look at the interactions indicated that the presence of heteroatoms such as oxygen and nitrogen was critical to how the compound binds [59]

(5) Generally speaking, H-acceptor interaction dominates the binding of the synthesized complexes to different receptors besides the metal binding to the protein backbone

\section{Conclusion}

A new diazo ligand, 2,2'-(1,3-phenylenebis(diazene-2,1diyl))bis(4-aminobenzoic acid), was synthesized and treated with different metal salts to give the corresponding metal complexes. The new ligand $\mathrm{H}_{2} \mathrm{~L}$ reacted with the metal ions 
as $1: 1$ unit. The analytical data showed that reactions of the free diazo ligand $\left(\mathrm{H}_{2} \mathrm{~L}\right)$ with $\mathrm{Mn}(\mathrm{II}), \mathrm{Co}(\mathrm{II}), \mathrm{Ni}(\mathrm{II}), \mathrm{Cu}(\mathrm{II})$, $\mathrm{Zn}(\mathrm{II})$, and $\mathrm{Cd}(\mathrm{II})$ formed complexes with chemical formulae $\left[\mathrm{M}\left(\mathrm{H}_{2} \mathrm{~L}\right) \mathrm{Cl}_{2}\right] \cdot \mathrm{nH}_{2} \mathrm{O} \quad(\mathrm{M}=\mathrm{Co}(\mathrm{II}), \mathrm{Ni}(\mathrm{II}), \mathrm{Cu}(\mathrm{II})$, $\mathrm{Mn}(\mathrm{II}), \mathrm{Zn}(\mathrm{II})$ and $\mathrm{Cd}(\mathrm{II}))$ and $\left[\mathrm{M}\left(\mathrm{H}_{2} \mathrm{~L}\right) \mathrm{Cl}_{2}\right] \mathrm{Cl} \cdot \mathrm{nH}_{2} \mathrm{O}$ $(\mathrm{M}=\mathrm{Cr}(\mathrm{III})$ and $\mathrm{Fe}(\mathrm{III}))$. The possible structures of the ligand and its metal-azo complexes were proposed based on elemental analyses, ${ }^{1} \mathrm{H}$ NMR, ESR, MS, IR, and UV-Vis electronic absorption. It was concluded that the $\mathrm{H}_{2} \mathrm{~L}$ ligand behaved as a neutral tetradentate ligand with $\mathrm{N}$ coordination sites and protonated carboxylate oxygen upon coordination to the metal ions leading to the formation of octahedral geometries for all complexes. The thermal studies for the compounds showed a higher thermal stability for the complexes than that of the free ligand. This may be due to chelation, the type, and the number of solvents of crystallization in the metal complexes. Also, the ligand and its metal complexes were screened in vitro against microorganisms (bacteria or fungi). The results of biological activity showed that the $\mathrm{Cd}(\mathrm{II})$ complex had higher antibacterial activity against the (Gram-positive) bacteria and fungi, while $\mathrm{Co}$ (II) had higher antibacterial activity against the (Gramnegative) bacteria compared to the free ligand and other metal complexes. Molecular docking studies of the free ligand and the $\mathrm{Cd}(\mathrm{II})$ complex with four different receptors clarified that the Cd(II) complex showed the minimum binding ability with the binding energy of $-18 \mathrm{kcal} / \mathrm{mol}$ with the crystal structure of $S$. aureus $(3 \mathrm{Q} 8 \mathrm{U})$.

\section{Data Availability}

The data used to support the findings of this study are available from the corresponding author upon request.

\section{Conflicts of Interest}

The authors declare no conflicts of interest.

\section{Supplementary Materials}

Supplementary Table (1): analytical and physical data of $\mathrm{H}_{2} \mathrm{~L}$ and its metal complexes. Supplementary Table (2): IR spectra $\left(4000-400 \mathrm{~cm}^{-1}\right)$ of $\mathrm{H}_{2} \mathrm{~L}$ and its metal complexes. Supplementary Table (5): different optimized parameters of $\mathrm{H}_{2} \mathrm{~L}$ and $\left[\mathrm{Cd}\left(\mathrm{H}_{2} \mathrm{~L}\right) \mathrm{Cl} 2\right] . \mathrm{H}_{2} \mathrm{O}$ complex. Supplementary Table (6): different Mulliken charges of $\mathrm{H}_{2} \mathrm{~L}$ and $\left[\mathrm{Cd}\left(\mathrm{H}_{2} \mathrm{~L}\right) \mathrm{Cl} 2\right] \cdot \mathrm{H}_{2} \mathrm{O}$ complex. Supplementary Figure 3: contact angle images of (a) $\mathrm{Cr}(\mathrm{III})$, (b) $\mathrm{Mn}$ (II), (c) $\mathrm{Fe}(\mathrm{III})$, (d) $\mathrm{Co}(\mathrm{II})$, (e) $\mathrm{Ni}(\mathrm{II})$, (f) $\mathrm{Cu}(\mathrm{II})$, (g) $\mathrm{Zn}(\mathrm{II})$, and (h) $\mathrm{Cd}(\mathrm{II})$ complexes and (i) $\mathrm{H}_{2} \mathrm{~L}$ ligand. Supplementary Figure 6: comparison of Mulliken charges for (a) free $\mathrm{H}_{2} \mathrm{~L}$ and (b) cadmium complex. Supplementary Figure 8: the theoretical IR spectra of (a) $\mathrm{H}_{2} \mathrm{~L}$ and (b) $\left[\mathrm{Cd}\left(\mathrm{H}_{2} \mathrm{~L}\right)\right.$ $\left.\mathrm{Cl}_{2}\right] \cdot \mathrm{H}_{2} \mathrm{O}$ and the experimental IR spectra of (c) $\mathrm{H}_{2} \mathrm{~L}$ and (d) $\left[\mathrm{Cd}\left(\mathrm{H}_{2} \mathrm{~L}\right) \mathrm{Cl}_{2}\right] \cdot \mathrm{H}_{2} \mathrm{O}$. (Supplementary Materials)

\section{References}

[1] X. Li, Y. Wu, D. Gu, and F. Gan, "Spectral, thermal and optical properties of metal(II)-azo complexes for optical recording media," Dyes and Pigments, vol. 86, no. 2, pp. 182-189, 2010.
[2] M. C. Garrigós, F. Reche, M. L. Marín, and A. Jiménez, "Determination of aromatic amines formed from azo colorants in toy products," Journal of Chromatography A, vol. 976, no. 1-2, pp. 309-317, 2002.

[3] Y. Karaman, N. Menek, F. A. Bicer, and H. Olmez, "Voltammetric investigations of 2,2'-azobispyridine $\operatorname{zinc}(\mathrm{II})$ and nickel(II) complexes," International Journal of Electrochemical Science, vol. 10, pp. 3106-3116, 2010.

[4] A. Khalil, N. M. Aboamera, W. S. Nasser, W. H. Mahmoud, and G. G. Mohamed, "Photodegradation of organic dyes by $\mathrm{PAN} / \mathrm{SiO}_{2}-\mathrm{TiO}_{2}-\mathrm{NH}_{2}$ nanofiber membrane under visible light," Separation and Purification Technology, vol. 224, pp. 509-514, 2019.

[5] J. Sima, "Mechanism of photoredox reactions of iron(III) complexes containing salen-type ligands," Croatica Chemica Acta, vol. 74, p. 593, 2001.

[6] J. T. Simpson, S. R. Hunter, and T. Aytug, "Superhydrophobic materials and coatings, a review," Reports on Progress in Physics, vol. 78, Article ID 086501, 2015.

[7] E. J. Falde, S. T. Yohe, Y. L. Colson, and M. W. Grinstaff, "Superhydrophobic Materials for Biomedical Applications," Biomaterials, vol. 104, pp. 87-103, 2016.

[8] T. A. Halgren, "Merck molecular force field. I. Basis, form, scope, parameterization, and performance of MMFF94," Journal of Computational Chemistry, vol. 17, no. 5-6, pp. 490-519, 1998.

[9] I. Sakiyan, E. Loğoğlu, S. Arslan, N. Sari, and N. Sakiyan, "Antimicrobial activities of N-(2-hydroxy-1-naphthalidene)amino acid(glycine, alanine, phenylalanine, histidine, tryptophane) Schiff bases and their manganese(III) complexes," Biometals: An International Journal on the Role of Metal Ions in Biology, Biochemistry, and Medicine, vol. 17, no. 2, pp. 115-120, 2004.

[10] P. Skehan, R. Storeng, D. Scudiero et al., "New colorimetric cytotoxicity assay for anticancer-drug screening," JNCI Journal of the National Cancer Institute, vol. 82, no. 13, pp. 1107-1112, 1990.

[11] S. Sangilipandi, D. Sutradhar, K. Bhattacharjee et al., "Synthesis, structure, antibacterial studies and DFT calculations of arene ruthenium, $\mathrm{Cp} * \mathrm{Rh}, \mathrm{Cp} * \mathrm{Ir}$ and tricarbonylrhenium metal complexes containing 2-chloro-3-(3-(2-pyridyl)pyrazolyl)quinoxaline ligand," Inorganica Chimica Acta, vol. 441, pp. 95-108, 2016.

[12] Chemical Computing Group Inc., Molecular Operating Environment (MOE 2008.10), Chemical Computing Group Inc., Montreal, QC, Canada, 2008.

[13] A.-N. M. A. Alaghaz, H. A. Bayoumi, Y. A. Ammar, and S. A. Aldhlmani, "Synthesis, characterization, and antipathogenic studies of some transition metal complexes with N,O-chelating Schiff's base ligand incorporating azo and sulfonamide Moieties," Journal of Molecular Structure, vol. 1035, pp. 383-399, 2013.

[14] M. M. Abo-Aly, A. M. Salem, M. A. Sayed, and A. A. Abdel Aziz, "Spectroscopic and structural studies of the Schiff base 3-methoxy-N-salicylidene-o-amino phenol complexes with some transition metal ions and their antibacterial, antifungal activities," Spectrochimica Acta Part A: Molecular and Biomolecular Spectroscopy, vol. 136, pp. 993-1000, 2015.

[15] I. Babahan, S. Emirdağ-Öztürk, and E. Poyrazoğlu-Çoban, "Spectroscopic and biological studies of new mononuclear metal complexes of a bidentate NN and NO hydrazone-oxime ligand derived from egonol," Spectrochimica Acta Part A: Molecular and Biomolecular Spectroscopy, vol. 141, pp. 300306, 2015. 
[16] G. G. Mohamed, H. F. Abd El-Halim, M. M. I. El-Dessouky, and W. H. Mahmoud, "Synthesis and characterization of mixed ligand complexes of lomefloxacin drug and glycine with transition metals. Antibacterial, antifungal and cytotoxicity studies," Journal of Molecular Structure, vol. 999, no. 1-3, pp. 29-38, 2011.

[17] H. Naeimi, J. Safari, and A. Heidarnezhad, "Synthesis of Schiff base ligands derived from condensation of salicylaldehyde derivatives and synthetic diamine," Dyes and Pigments, vol. 73, no. 2, pp. 251-253, 2007.

[18] M. Hanif and Z. H. Chohan, "Design, spectral characterization and biological studies of transition metal(II) complexes with triazole Schiff bases," Spectrochimica Acta Part A: Molecular and Biomolecular Spectroscopy, vol. 104, pp. 468-476, 2013.

[19] A. Maiti and S. Ghosh, "Synthesis and reactivity of the oxovanadium(IV) complexes of two NO donors and potentiation of the antituberculosis activity of one of them on chelation to metal ions: Part IV," Journal of Inorganic Biochemistry, vol. 36, no. 2, pp. 131-139, 1989.

[20] R. G. Deghadi, W. H. Mahmoud, and G. G. Mohamed, "Metal complexes of tetradentate azo-dye ligand derived from 4,4'oxydianiline; Preparation, structural investigation, biological evaluation and MOE studies," Accepted Manuscript Applied Organometallic Chemistry, vol. 34, no. 10, 2020.

[21] V. L. Dorofeev, "Infrared spectra and the structure of drugs of the fluoroquinolone group," Pharmaceutical Chemistry Journal, vol. 38, pp. 45-49, 2004.

[22] M. S. Refat, G. G. Mohamed, R. F. de Farias et al., "Spectroscopic, thermal and kinetic studies of coordination compounds of $\mathrm{Zn}(\mathrm{II}), \mathrm{Cd}(\mathrm{II})$ and $\mathrm{Hg}(\mathrm{II})$ with norfloxacin," Journal of Thermal Analysis and Calorimetry, vol. 102, no. 1, pp. 225-232, 2010.

[23] N. G. Zaki, W. H. Mahmoud, A. M. El Kerdawy El Kerdawy, A. M. Abdallah, and G. G. Mohamed, "Heteroleptic complexes of cocaine/TMEDA with some $f$ block metals: synthesis, DFT studies, spectral, thermal, cytotoxicity and antimetastatic properties," Spectrochimica Acta Part A: Molecular and Biomolecular Spectroscopy, vol. 229, Article ID 117938, 2020.

[24] L. J. Bellamy, The Infrared Spectra of Complex Molecules, Chapman and Hall, London, UK, third edition, 1975.

[25] K. Nakamoto, Infrared Spectra of Inorganic and Coordination Compounds, Wiley Interscience, New York, NY, USA, 1970.

[26] W. H. Mahmoud, G. G. Mohamed, and M. M. I. El-Dessouky, "Coordination modes of bidentate lornoxicam drug with some transition metal ions. Synthesis, characterization and in vitro antimicrobial and antibreastic cancer activity studies," Spectrochimica Acta Part A: Molecular and Biomolecular Spectroscopy, vol. 122, pp. 598-608, 2014.

[27] W. H. Mahmoud, F. N. Sayed, and G. G. Mohamed, "Azo dye with nitrogen donor sets of atoms and its metal complexes: synthesis, characterization, DFT, biological, anticancer and Molecular docking studies," Applied Organometallic Chemistry, vol. 32, pp. 1-19, Article ID e4347, 2018.

[28] R. Cini, G. Giorgi, A. Cinquantini, C. Rossi, and M. Sabat, "Metal complexes of the antiinflammatory drug piroxicam," Inorganic Chemistry, vol. 29, no. 26, pp. 5197-5200, 1990.

[29] Y.-T. Liu, G.-D. Lian, D.-W. Yin, and B.-J. Su, "Synthesis, characterization and biological activity of ferrocene-based Schiff base ligands and their metal (II) complexes," Spectrochimica Acta Part A: Molecular and Biomolecular Spectroscopy, vol. 100, pp. 131-137, 2013.
[30] H. Irving and R. J. P. Williams, "637. The stability of transition-metal complexes," Journal of the Chemical Society (Resumed), vol. 75, pp. 3192-3210, 1953.

[31] W. H. Mahmoud, N. F. Mahmoud, G. G. Mohamed, A. Z. ElSonbati, and A. A. El-Bindary, "Ternary metal complexes of guaifenesin drug: synthesis, spectroscopic characterization and in vitro anticancer activity of the metal complexes," Spectrochimica Acta Part A: Molecular and Biomolecular Spectroscopy, vol. 150, no. 1, pp. 451-460, 2015.

[32] G. G. Mohamed, E. M. Zayed, and A. M. M. Hindy, "Coordination behavior of new bis Schiff base ligand derived from 2-furan carboxaldehyde and propane-1,3-diamine. Spectroscopic, thermal, anticancer and antibacterial activity studies," Spectrochimica Acta Part A: Molecular and Biomolecular Spectroscopy, vol. 145, pp. 76-84, 2015.

[33] W. Chen, Y. Wu, D. Gu, and F. Gan, "Synthesis, optical and thermal characterization of novel thiazolyl heterocyclic azo dye," Materials Letters, vol. 61, no. 19-20, pp. 4181-4184, 2007.

[34] M. R. Mahmoud, A. M. Hamman, and S. A. Ibrahim, "Chromium complexes of O,O-dihydroxyazo dye," Zeitschrift für Physikalische Chemie, vol. 265, pp. 203-211, 1994.

[35] P. Subbaraj, A. Ramu, N. Raman, and J. Dharmaraja, "Synthesis, characterization, DNA interaction and pharmacological studies of substituted benzophenone derived Schiff base metal(II) complexes," Journal of Saudi Chemical Society, vol. 19, no. 2, pp. 207-216, 2015.

[36] N. Kavitha and P. V. Anantha Lakshmi, "Synthesis, characterization and thermogravimetric analysis of $\mathrm{Co}(\mathrm{II}), \mathrm{Ni}(\mathrm{II})$, $\mathrm{Cu}(\mathrm{II})$ and $\mathrm{Zn}(\mathrm{II})$ complexes supported by ONNO tetradentate Schiff base ligand derived from hydrazino benzoxazine," Journal of Saudi Chemical Society, vol. 21, pp. S457-S466, 2017.

[37] W. H. Mahmoud, T. A. Awed, and G. G. Mohamed, "Construction and characterization of nano iron complex ionophore for electrochemical determination of $\mathrm{Fe}(\mathrm{III})$ in pure and different real water samples," Applied Organometallic Chemistry, vol. 33, pp. 1-17, Article ID e5206, 2019.

[38] A. M. F. Benial, V. Ramakrishnan, and R. Murugesan, "Single crystal EPR of $\mathrm{Cu}(\mathrm{C} 5 \mathrm{H} 5 \mathrm{NO}) 6(\mathrm{BF} 4) 2$ : an example of admixed ground state," Spectrochimica Acta Part A: Molecular and Biomolecular Spectroscopy, vol. 56, no. 14, pp. 2775-2781, 2000.

[39] K. B. Gudasi, S. A. Patil, R. S. Vadavi, R. V. Shenoy, and M. Nethaji, "Crystal structure of 2-[2-hydroxy-3-methoxyphenyl]-3-[2-hydroxy-3-methoxybenzylamino]-1,2-dihydroquinazolin-4(3H)-one and the synthesis, spectral and thermal investigation of its transition metal complexes," Transition Metal Chemistry, vol. 31, no. 5, pp. 586-592, 2006.

[40] A. Z. El-Sonbati, M. A. Diab, A. A. El-Bindary, G. G. Mohamed, and S. M. Morgan, "Thermal, spectroscopic studies and hydrogen bonding in supramolecular assembly of azo rhodanine complexes," Inorganica Chimica Acta, vol. 430, pp. 96-107, 2015.

[41] N. A. El-Ghamaz, M. A. Diab, A. A. El-Bindary, A. Z. ElSonbati, and S. G. Nozha, "Thermal, dielectric characteristics and conduction mechanism of azodyes derived from quinoline and their copper complexes," Spectrochimica Acta Part A: Molecular and Biomolecular Spectroscopy, vol. 143, pp. 200-212, 2015.

[42] S. Velumani, X. Mathew, P. J. Sebastian, S. K. Narayandass, and D. Mangalaraj, "Structural and optical properties of hot wall deposited CdSe thin films," Solar Energy Materials and Solar Cells, vol. 76, no. 3, pp. 347-358, 2003. 
[43] S. Basavaraja, D. S. Balaji, M. D. Bedre, D. Raghunandan, P. M. Prithviraj Swamy, and A. Venkataraman, "Solvothermal synthesis and characterization of acicular $\alpha$-Fe2O3 nanoparticles," Bulletin of Materials Science, vol. 34, no. 7, pp. 1313-1317, 2011.

[44] T. A. Yousef, O. K. Alduaij, S. F. Ahmed, G. M. Abu El-Reash, and O. A. El-Gammal, "Structural, DFT and biological studies on $\mathrm{Cr}$ (III) complexes of semi and thiosemicarbazide ligands derived from diketo hydrazide," Journal of Molecular Structure, vol. 1125, pp. 788-799, 2016.

[45] W. A. Zordok and S. A. Sadeek, "Synthesis, thermal analyses, characterization and biological evaluation of new enrofloxacin vanadium $(\mathrm{V})$ solvates $(\mathrm{L})(\mathrm{L}=\mathrm{An}, \mathrm{DMF}, \mathrm{Py}, \mathrm{Et} 3 \mathrm{~N}$ and o-Tol)," Journal of Molecular Structure, vol. 1120, pp. 50-61, 2016.

[46] R. Takjoo, S. S. Hayatolgheibi, and H. Amiri Rudbari, "Preparation, X-ray structure, spectral analysis, DFT calculation and thermal study on palladium(II) coordination compound with Schiff base derived from S-allyldithiocarbazate," Inorganica Chimica Acta, vol. 447, pp. 52-58, 2016.

[47] S. Altürk, D. Avcı, Ö. Tamer, Y. Atalay, and O. Şahin, "A cobalt (II) complex with 6-methylpicolinate: synthesis, characterization, second- and third-order nonlinear optical properties, and DFT calculations," Journal of Physics and Chemistry of Solids, vol. 98, pp. 71-80, 2016.

[48] W. H. Mahmoud, M. M. Omar, and F. N. Sayed, "Synthesis, spectral characterization, thermal, anticancer and antimicrobial studies of bidentate azo dye metal complexes," Journal of Thermal Analysis and Calorimetry, vol. 124, no. 2, pp. 1071-1089, 2016.

[49] M. J. Pelczar, E. C. S. Chan, and N. R. Krieg, "Host-parasite interaction; nonspecific host resistance," in Microbiology Concepts and Applications, pp. 478-479, McGraw-Hill Inc., New York, NY, USA., 6th edition, 1999.

[50] W. H. Mahmoud, F. N. Sayed, and G. G. Mohamed, "Synthesis, characterization andin vitroantimicrobial and antibreast cancer activity studies of metal complexes of novel pentadentate azo dye ligand," Applied Organometallic Chemistry, vol. 30, no. 11, pp. 959-973, 2016.

[51] A. T. Çolak, F. Çolak, O. Z. Yeşilel, D. Akduman, F. Yılmaz, and M. Tümer, "Supramolecular cobalt(II)-pyridine-2,5dicarboxylate complexes with isonicotinamide, 2-amino-3methylpyridine and 2-amino-6-methylpyridine: syntheses, crystal structures, spectroscopic, thermal and antimicrobial activity studies," Inorganica Chimica Acta, vol. 363, no. 10, pp. 2149-2162, 2010.

[52] S. Belaid, A. Landreau, S. Djebbar, O. Benali-Baitich, G. Bouet, and J.-P. Bouchara, "Synthesis, characterization and antifungal activity of a series of manganese(II) and copper(II) complexes with ligands derived from reduced N,N'-O-phenylenebis(salicylideneimine)," Journal of Inorganic Biochemistry, vol. 102, no. 1, pp. 63-69, 2008.

[53] K. Kralova, K. Kwassova, O. Svajlenova, and J. Vanco, "Chem. Biological activity of copper(II) N-salicylideneaminoacidato complexes. Reduction of chlorophyll content in freshwater alga chlorella vulgaris and inhibition of photosynthetic electron transport in Spinach chloroplasts," Chemical Papers, vol. 58, pp. 357-361, 2004.

[54] R. Nair, A. Shah, S. Baluja, and S. Chanda, "Synthesis and antibacterial activity of some Schiff base complexes," Journal of the Serbian Chemical Society, vol. 71, no. 7, pp. 733-744, 2006.

[55] Y. Vaghasia, R. Nair, M. Soni, S. Baluja, and S. Chanda, "Synthesis, structural determination and antibacterial activity of compounds derived from vanillin and 4-aminoantipyrine," J. Serb. Chem. Soc.vol. 69, pp. 991-998, 2004.

[56] N. Mahalakshmi and R. Rajavel, "Synthesis, spectroscopic, DNA cleavage and antibacterial activity of binuclear schiff base complexes," Arabian Journal of Chemistry, vol. 7, no. 4, pp. 509-517, 2014.

[57] E. K. Efthimiadou, A. Karaliota, and G. Psomas, "Mononuclear metal complexes of the second-generation quinolone antibacterial agent enrofloxacin: synthesis, structure, antibacterial activity and interaction with DNA," Polyhedron, vol. 27, no. 6, pp. 1729-1738, 2008.

[58] F. A. Beckford, A. Brock, A. Gonzalez-Sarrías, and N. P. Seeram, "Cytotoxic gallium complexes containing thiosemicarbazones derived from 9-anthraldehyde: molecular docking with biomolecules," Journal of Molecular Structure, vol. 1121, pp. 156-166, 2016.

[59] K. Zheng, M.-X. Yan, Y.-T. Li, Z.-Y. Wu, and C.-W. Yan, "Synthesis and structure of new dicopper(II) complexes bridged by $\mathrm{N}$-(2-hydroxy-5-methylphenyl)- $\mathrm{N}^{\prime}$-[3-(dimethylamino)propyl]oxamide with in vitro anticancer activity: a comparative study of reactivities towards DNA/protein by molecular docking and experimental assays," European Journal of Medicinal Chemistry, vol. 109, pp. 47-58, 2016.

[60] G. M. Morris, D. S. Goodsell, R. S. Halliday et al., "Automated docking using a Lamarckian genetic algorithm and an empirical binding free energy function," Journal of Computational Chemistry, vol. 19, no. 14, pp. 1639-1662, 1998. 